\title{
Ecogenomics of the Marine Benthic Filamentous Cyanobacterium Adonisia
}

\author{
Juline M. Walter ${ }^{1,2}$ (1) - Felipe H. Coutinho ${ }^{1,2}$ - Luciana Leomil ${ }^{1}$ • Paulo I. Hargreaves ${ }^{1}$ - Mariana E. Campeão ${ }^{1}$. \\ Verônica V. Vieira ${ }^{3}$ - Beatriz S. Silva ${ }^{4}$. Giovana O. Fistarol ${ }^{4}$. Paulo S. Salomon ${ }^{4} \cdot$ Tomoo Sawabe $^{5}$. Sayaka Mino ${ }^{5}$. \\ Masashi Hosokawa ${ }^{5} \cdot$ Hideaki Miyashita ${ }^{6}$. Fumito Maruyama ${ }^{6} \cdot$ Marcel C. van Verk ${ }^{7}$. Bas E. Dutilh ${ }^{2,8}$. \\ Cristiane C. Thompson ${ }^{1} \cdot$ Fabiano L. Thompson ${ }^{1,9}$ (D)
}

Received: 18 April 2019 / Accepted: 22 December 2019/Published online: 14 February 2020

(C) Springer Science+Business Media, LLC, part of Springer Nature 2020

\begin{abstract}
Turfs are among the major benthic components of reef systems worldwide. The nearly complete genome sequences, basic physiological characteristics, and phylogenomic reconstruction of two phycobiliprotein-rich filamentous cyanobacteria strains isolated from turf assemblages from the Abrolhos Bank (Brazil) are investigated. Both Adonisia turfae CCMR0081 ${ }^{\mathrm{T}}$ (= CBAS $745^{\mathrm{T}}$ ) and CCMR0082 contain approximately $8 \mathrm{Mbp}$ in genome size and experiments identified that both strains exhibit chromatic acclimation. Whereas CCMR0081 $1^{\mathrm{T}}$ exhibits chromatic acclimation type 3 (CA3) regulating both phycocyanin (PC) and phycoerythrin (PE), CCMR0082 strain exhibits chromatic acclimation type 2 (CA2), in correspondence with genes encoding specific photosensors and regulators for PC and PE. Furthermore, a high number and diversity of secondary metabolite synthesis gene clusters were identified in both genomes, and they were able to grow at high temperatures $\left(28{ }^{\circ} \mathrm{C}\right.$, with scant growth at $30{ }^{\circ} \mathrm{C}$ ). These characteristics provide insights into their widespread distribution in reef systems.
\end{abstract}

Keywords Microbial ecology $\cdot$ Cyanobacteria $\cdot$ Turf $\cdot$ Coral reefs $\cdot$ Abrolhos Bank $\cdot$ Secondary metabolites $\cdot$ Photoacclimation strategies

\section{Introduction}

Cyanobacteria are among the most diverse groups of prokaryotic organisms, comprising unicellular and multicellular, photosynthetic and heterotrophic, and free-living and symbiotic

Electronic supplementary material The online version of this article (https://doi.org/10.1007/s00248-019-01480-x) contains supplementary material, which is available to authorized users.

Fabiano L. Thompson

fabianothompson1@gmail.com

1 Laboratory of Microbiology, Institute of Biology, Federal University of Rio de Janeiro (UFRJ), Rio de Janeiro, Brazil

2 Radboud Institute for Molecular Life Sciences, Centre for Molecular and Biomolecular Informatics (CMBI), Radboud University Medical Centre, Nijmegen, The Netherlands

3 Instituto Oswaldo Cruz (IOC), FIOCRUZ, Rio de Janeiro, Brazil

4 Marine Phytoplankton Laboratory, Institute of Biology, Federal University of Rio de Janeiro (UFRJ), Rio de Janeiro, Brazil

5 Faculty of Fisheries Sciences, Hokkaido University, Hakodate, Japan forms. They are the earliest oxygenic photosynthetic organisms and correspond to a relevant global biomass on the order of $10^{14} \mathrm{~g} \mathrm{C}$ [1], accounting for 20-30\% of Earth's photosynthetic productivity $[2,3,4,5]$. Coupled with their photosynthetic abilities and roles to global carbon, cyanobacteria are

6 Office of Academic Research and Industry-Government Collaboration, Hiroshima University, 739-8530, Hiroshima, Japan

7 Plant-Microbe Interactions, Bioinformatics, Faculty of Science, Utrecht University, Utrecht, The Netherlands

8 Theoretical Biology and Bioinformatics, Utrecht University, Utrecht, The Netherlands

9 Center of Technology-CT2, SAGE-COPPE, Federal University of Rio de Janeiro (UFRJ), Av. Carlos Chagas Filho, 373, CCS-IB-Biomar, Lab. de Microbiologia, Bloco A3, (Anexo), sl. 102, Cidade Universitária, Rio de Janeiro, RJ CEP 21941-599, Brazil 
ecologically important for their contributions to nitrogen fixation [6] and carbonate precipitation [7], regulating these essential cycles.

The immense diversity within this group of microorganisms is also reflected in the extent of their secondary metabolites, which mediate cell-cell communication, protection, competition and interactions with other organisms and the environment $[8,9,10]$. Furthermore, a great number of evolved acclimation strategies have contributed to species exploit a wide range of light niches [11, 12-14, 15], allowing them to survival in highly competitive ecological niches, such as benthic compartments of reef systems. When conditions limit cell growth (i.e. diffuse/low light or excess irradiation), cyanobacteria are able to largely reshape their photoapparatus by altering their total chlorophyll and phycobiliprotein contents and adjusting their photosystem ratio. Additionally, secondary metabolites produced by these microorganisms allow them to survive under stressful conditions [16, 17]. Early studies were focused on freshwater strains (e.g. Planktothrix agardhii, Planktothrix rubescens, Microcystis aeruginosa) and the deleterious effects of their potent toxins to humans and wildlife in aquatic systems [18], and marine representatives were recently revealed to be prolific secondary metabolite producers (e.g. Moorea, Lyngbya, Microcystis, Nostoc genera) [19-21]. These secondary metabolites may have antibacterial, antifungal, antiviral, anticancer, multidrug-reversing, anti-inflammatory, cholesterol-lowering, immunosuppressants, antiparasitic, herbicides, UV-protective and potent enzyme-inhibiting properties [22-33]. Among these compounds, the most common are polyketide synthases (PKSs), nonribosomal peptide synthases (NRPSs), hybrids thereof, alkaloids, terpenoids and amino glycosides [34, 35]. Clearly, both the gene cluster repertoire detected in cyanobacteria genomes and the diverse biological activity of certain cyanobacteria against viruses, microbes and eukaryotes hint at a powerful weaponry for occupying the environment.

Turfs are dense filamentous mats that represent one of the most abundant benthic functional groups in Atlantic, Caribbean and Pacific reefs [36-38]. Cyanobacteria are among the most abundant microorganisms in turfs from the Abrolhos reefs (Bahia, Brazil) [37] and play important physical, structural and functional roles in these turfs [37]. However, the genomic and physiological properties of Abrolhos turf-forming cyanobacteria are not known. Coral reefs worldwide have experienced a phase-shifting phenomenon in which the coral cover is decreasing and the turf and macroalgae cover are increasing [39]. The major causes of this phase-shift are mediated by overfishing and outcomes of the dissolved organic matter, disease outbreaks, algae and microbes model (DDAM model) [40-45]. Despite understanding of the ecologic relevance of turfs in reef systems worldwide, issues related to the pathogenic (toxic) potential of different turf- forming cyanobacteria and their potential for niche construction/alteration are still being deciphered.

The aim of the present study was to determine the genomic and physiological potential of two filamentous cyanobacteria from the Abrolhos reefs. First, cultures were obtained for $\mathrm{CCMR} 0081^{\mathrm{T}}$ and CCMR0082, and their growth rates and photosynthetic pigments were determined. The genomes of these two strains were assembled into 16 and 21 scaffolds, respectively. The phylogenetic and taxonomic positions of the two strains were determined and they are placed in a novel phylogenetic branch designated Adonisia turfae sp. nov. The two strains were analysed thoroughly, including detailed evaluation of their pigments, acclimation responses, $\mathrm{H}_{2}$ production and secondary metabolite gene contents, to identify possible cues regarding the ecological relevance of these strains in reef systems. Finally, sequence comparison of the genomes of Adonisia turfae sp. nov. CCMR0081 ${ }^{\mathrm{T}}$ and CCMR0082 with 19 previously published turf metagenomes [37] allowed us to determine the frequency of the occurrence of these two strains in different reefs from the Abrolhos Bank. The identified physiological and ecogenomic attributes are significant, as these cyanobacteria may be on the rise in reef habitats as the climate changes.

\section{Materials and Methods}

\section{Source of Organism, Isolation and Cultivation}

The cyanobacteria strains reported herein were isolated from turf samples growing over the corals from the Abrolhos reefs

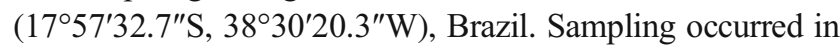
March and October 2013 by scuba diving (approx. $10 \mathrm{~m}$ depth), under a federal government licence (SISBIO no. 27147-2). Samples were kept at ambient temperature and protected from direct sunlight with the flask lids untightened; these flasks were transported to the laboratory for isolation. Upon arrival, turf samples were enriched with $\mathrm{f} / 2$ medium [46, 47] prepared with $0.22 \mu \mathrm{m}$ filtered Abrolhos seawater, and kept at $22{ }^{\circ} \mathrm{C}$ under a $16 / 8$-h light/dark cycle and light intensity of $80 \mu \mathrm{mol}$ photons $\mathrm{m}^{-2} \mathrm{~s}^{-1}$ supplied with cool white fluorescent lamps. As a first cleaning step, cyanobacterial filaments were manually picked from the turf samples and rinsed with five serial transfers through drops of sterile $\mathrm{f} / 2$ medium and incubated under the conditions described above for 10 days. The filaments were fragmented by sonication (Ultrasonic Processor/Cell Disruptor, 130-W Cole-Parmer Instrument Co., USA), for 1 min alternated $5 \mathrm{~s}$ on/off pulses at $20 \%$ power. Single fragments of filaments were sorted by Fluorescence Activated Cell Sorting (FACS) in a MoFlo (Dako Cytomation) flow cytometer into the wells of 96-well microplates containing $f / 2$ medium. Cultures that grew in the wells within 4 to 6 weeks were transferred to fresh culture 
medium. The two strains reported herein were added to the Culture Collection of Microorganisms at the Federal University of Rio de Janeiro (CCMR) under the codes CCMR0081 ${ }^{\mathrm{T}}$ and CCMR0082. The strains were cryopreserved in liquid $\mathrm{N}_{2}$ using $5 \%$ DMSO for long-term storage. Cultures were maintained as a unicyanobacterial but nonaxenic culture. Axenic cultures of filamentous cyanobacteria are difficult to obtain due to the heterotrophic bacteria strongly associated at the sheath (e.g. $[48,49])$.

\section{Growth Rate Estimates}

Both cyanobacterial strains were grown in $100 \mathrm{~mL}$ tissueculture bottles in $\mathrm{f} / 2$ medium made with Abrolhos seawater at an irradiance of $50 \mu \mathrm{E} \mathrm{m}^{-2} \mathrm{~s}^{-2}$ with a 16/8-h light/dark cycle at 24 and $26{ }^{\circ} \mathrm{C}$. Filaments from 7-day-old cultures of each strain were homogenized by gentle mechanical disruption in a sonicator (Ultrasonic Processor/Cell Disruptor, 130W Cole-Parmer Instrument Co., USA, 1 min alternated $1 \mathrm{~s} \mathrm{on} /$ off pulses at $10 \%$ power). The homogeneous filament suspensions were diluted with fresh $\mathrm{f} / 2$ medium and $150 \mu \mathrm{L}$ each were transferred (4 replicates for each strain and temperature) to the wells of 96-well polystyrene microplates. The plates were incubated using the same irradiance and temperature conditions as above. Growth in each well was followed by daily in vivo chlorophyll fluorescence measurements for 5 days in a spectrofluorometer (Varian Cary Eclipse, $\lambda_{\text {ex }}$ $\left.450 \mathrm{~nm}, \lambda_{\mathrm{em}} 678 \mathrm{~nm}\right)$. Specific growth rates $\left(\mu, \mathrm{d}^{-1}\right)$ were calculated as the slope between the Ln of chlorophyll fluorescence vs. time in the linear portion of the growth curves. Doubling times ( $G$, day) were calculated as $\operatorname{Ln} 2 / \mu$.

\section{Cell-Size Measurements}

Filaments of both strains CCMR0081 ${ }^{\mathrm{T}}$ and CCMR0082 harvested from 10-day-old cultures were observed in an upright microscope (Olympus BX51) at $\times 1000$ magnification. The linear dimensions (length and width) of 50 cells from each strain were measured using a calibrated ruler printed on the microscope's ocular.

\section{In Vivo Absorption Spectra}

Cultures of both strains were grown at $24{ }^{\circ} \mathrm{C}$ as explained above for the growth rate estimates. In vivo absorption spectra were obtained by scanning homogeneous 7-day-old cyanobacterial filament suspensions from 400 to $700 \mathrm{~nm}$ in a dual-beam spectrophotometer (Femto Cirrus 80ST) with $1 \mathrm{~cm}$ optical path quartz cuvettes using $\mathrm{f} / 2$ medium as a blank. Spectra were normalized at the chlorophyll $a$ blue peak (442 nm).

\section{Chromatic Acclimation Evaluation}

Strains CCMR0081 ${ }^{\mathrm{T}}$ and CCMR0082 were continuously grown in the laboratory in $\mathrm{f} / 2$ medium at $25{ }^{\circ} \mathrm{C}$ under cool white fluorescent light lamp $(16 / 8 \mathrm{~h}$ photoperiod and light intensity of $50 \mu \mathrm{mol}$ photons $\mathrm{m}^{-2} \mathrm{~s}^{-1}$ ). To evaluate chromatic acclimation, cells were grown under Far-Red light (FRL, $\lambda>$ $700 \mathrm{~nm} ; 730 \mathrm{~nm}$ LED light $30 \mu \mathrm{mol}$ photons $\mathrm{m}^{-2} \mathrm{~s}^{-} 12 / 12 \mathrm{~h}$ photoperiod), and under dark control condition, for 21 days. Absorption spectra of CCMR0081 ${ }^{\mathrm{T}}$ and CCMR0082 cells suspended in a growth medium were measured with a UVVIS spectrometer (UV-2450, SHIMADZU, Kyoto, Japan). The white fluorescent light lamp used in this experiment would provide blue, green and red wavelengths (that penetrate deeper into the water column), while the Far-Red light (that penetrates at lower depths) would provide much longer wavelengths, covering a significant light spectrum range possibly present in the Abrolhos reefs.

\section{Photosynthetic Pigments Quantification}

Cultures of both strains were grown at $24{ }^{\circ} \mathrm{C}$ as explained above for the growth rate estimates. The biomass from triplicate, 10-day-old cultures of each strain was split in two approximately equal parts and the wet weight of each aliquot was determined. Filaments of both aliquots from each culture were harvested by filtration onto $25 \mathrm{~mm} \mathrm{GF} / \mathrm{F}$ glass-fibre discs. Biomass retained in one set of $\mathrm{GF} / \mathrm{F}$ discs was extracted overnight in $90 \%$ acetone for chlorophyll quantification by spectrofluorometry as described elsewhere [50]. The other filter set was extracted in $20 \mathrm{nM}$ sodium acetate buffer, pH 5.5, supplemented with $3 \mathrm{mM}$ sodium azide and $10 \mathrm{mM}$ disodium EDTA. Cells were ruptured by sonication (Ultrasonic Processor/Cell Disruptor, 130-W Cole-Parmer Instrument Co., USA, 5 min, 90\% power) in an ice bath alternating with freeze and thaw cycles. The crude extracts were treated with $1 \%(\mathrm{w} / \mathrm{v})$ streptomycin sulphate for $30 \mathrm{~min}$ at $4{ }^{\circ} \mathrm{C}$ and centrifuged at $10,000 \times g$ for $10 \mathrm{~min}$ to precipitate the cellular debris. Phycobiliprotein (phycoerythrin, phycocyanin, and allophycocyanin) concentrations were calculated from measurements of optical densities at 565, 620 and $650 \mathrm{~nm}$ in a spectrophotometer (FEMTO Cirrus 80ST) using the equations described in Bennett and Bogorad [51] and Bryant et al. [52]. The results were expressed as mass of pigment per wet weight of cyanobacterial biomass.

\section{Hydrogen Production Assay}

Cyanobacterial filaments patches concentrated in the culture tubes were collected and washed with $\mathrm{f} / 2$ media without $\mathrm{NaNO}_{3}$. The experiments were performed in $20 \mathrm{~mL}$ vials covered with gas-tight seals into which nitrogen and argon (i.e. absence of nitrogen gas) replaced the atmospheric air. The 
vials were incubated for 21 days at $25^{\circ} \mathrm{C}$ in darkness, in each condition. The replacement of the atmospheric air and the incubation in darkness (avoiding photosynthesis) were established because the presence of oxygen inhibits hydrogen production. Hydrogen quantification was carried by sampling $500 \mu \mathrm{L}$ from gas headspace and injecting in gas chromatographer (GC2014, Shimadzu, Kyoto, Japan) with a thermal conductivity detector and ShinCarbon ST column (Shinwa Chemical Industries Ltd., Kyoto, Japan). Hydrogen production is a surrogate for $\mathrm{N}_{2}$ fixation [53].

\section{Dry Weight Determination}

Filtered and washed cyanobacterial biomass was dried at $60{ }^{\circ} \mathrm{C}$ until stable weight was obtained.

\section{DNA Extraction and Library Construction}

Strains CCMR0081 ${ }^{\mathrm{T}}$ and CCMR0082 were grown in $250 \mathrm{~mL}$ Erlenmeyer flasks in $\mathrm{f} / 2$ medium to obtain cyanobacterial biomass for DNA extraction (Fig. S1). Genomic DNA was extracted using the Dneasy Plant Mini kit (Qiagen Inc., Valencia, CA, USA). The integrity of the DNA samples was evaluated using electrophoresis on a $1 \%$ agarose gel with GelRed ${ }^{\mathrm{TM}}$ (Biotium Inc., Hayward, CA, USA). The quality and purity of the DNA were assessed using a NanoDrop spectrophotometer (Thermo Fisher Scientific Inc., Waltham, MA, USA). The quantity and quality of the DNA in each sample used to construct the paired-end library were $317.3 \mathrm{ng} / \mu \mathrm{L}$ (A260/280 2.0 and $\mathrm{A} 260 / 2302.3$ ) for CCMR0081 ${ }^{\mathrm{T}}$ and $162.4 \mathrm{ng} / \mu \mathrm{L}$ (A260/280 2.0 and A260/230 1.6) for CCMR0082.

Accurate DNA quantification was obtained using the Qubit ${ }^{\circ}$ 3.0 Fluorometer (Life Technologies-Invitrogen, Carlsbad, CA, USA). The DNA libraries were built using the Nextera XT DNA Sample Preparation Kit (Illumina, San Diego, CA, USA). The size distribution of the libraries was evaluated using a 2100 Bioanalyser (Agilent, Santa Clara, CA, USA), and quantification was obtained using a 7500 Real-Time PCR Thermocycler (Applied Biosystems, Foster City, CA, USA) and the KAPA Library Quantification Kit (Kapa Biosystems, Wilmington, MA, USA).

\section{Acquisition of Whole-Genome Sequences}

Genomic DNAs were sequenced in an Illumina MiSeq pairedend flow cell (San Diego, CA, USA) $(2 \times 250$-bp read length) at the Laboratory of Microbiology, Federal University of Rio de Janeiro, Brazil. The fastq files generated by Illumina sequencing were checked for quality in both the forward and reverse directions with FastQC software [54]. Based on the sequence profiles, the files were filtered for end trimming, low-score sequence quality (sequences with Phred score < 30 were removed) and minimal length (sequences $<35 \mathrm{bp}$ in length were removed) using the FASTX-Toolkit version 0.0.12 [55] and PRINSEQ version 0.20.4 [56].

Genome assemblies were performed using Velvet version 1.2.10 [57] assembler tool (k-mer 89 for $\mathrm{CCMR}^{2} 081^{\mathrm{T}}$ and $\mathrm{k}$ mer 81 for CCMR0082). Emergent self-organizing maps (ESOM) are community-wide analysis of microbial genome sequence signatures, clustering sequences by tetranucleotide frequencies [58]. For that reason, ESOM-based approach has been used to visualizing and distinguishing sequences of multiple microorganisms in cultures assumed as axenic. It allows to detect and separate any associated bacterial sequences from the genome assemblies of interest. Even after careful isolation and cultivation procedures, cyanobacterial cultures often contain several different co-cultured bacteria [59], especially for the filamentous strains, which commonly hold heterotrophic bacteria associated in the cyanobacterial sheath. Reads were aligned back to the assembly where the Gap5 [60] and SPAdes version 3.5.0 [61] tools were used to improve scaffolds. Even after careful isolation and cultivation procedures, cyanobacterial cultures often contain several different cocultured bacteria, especially for the filamentous strains, which commonly hold heterotrophic bacteria associated in the cyanobacterial sheath. Approaches such as ESOM tool [58] above mentioned are able to detect and separate any heterotrophic bacterial sequences from the genome assemblies of interest. The assembly statistics were estimated using QUAST version 2.3 tool [62], and genome completeness and contamination level were accessed through CheckM [63] (Table 1).

\section{Genome Annotation}

Genomes were annotated using Prokka version 1.11 [64] with default settings, where Prodigal [65] is used for coding sequence (CDS) prediction, and RNAmmer [66] predicts ribosomal RNA genes (rRNA). tRNAscan-SE [67] was used to predict transfer RNA genes (tRNA). GC skew analysis was performed with Genome Skew version 1.0 [68], according to the formula $\mathrm{GC}$ skew $=(\mathrm{G}-\mathrm{C}) /(\mathrm{G}+\mathrm{C})$, and with the genome split into 9000 windows. The Cgview comparison tool [69] was used to create a genome-wide homology map.

\section{S rRNA Phylogeny and Genomic Taxonomy Analysis}

To establish the taxonomic placement of the new strains, phylogenetic trees were constructed using the small subunit ribosomal RNA (16S rRNA) sequences and the concatenated alignments of a set of conserved genes. We used the SILVA Incremental Aligner (SINA) [70] to search for significant 16S rRNA matches on the ARB SILVA SSU Ref non-redundant database [71, 72] (accessed on May 2017). The top 15 matches of each strain labelled as belonging to Leptolyngbya 


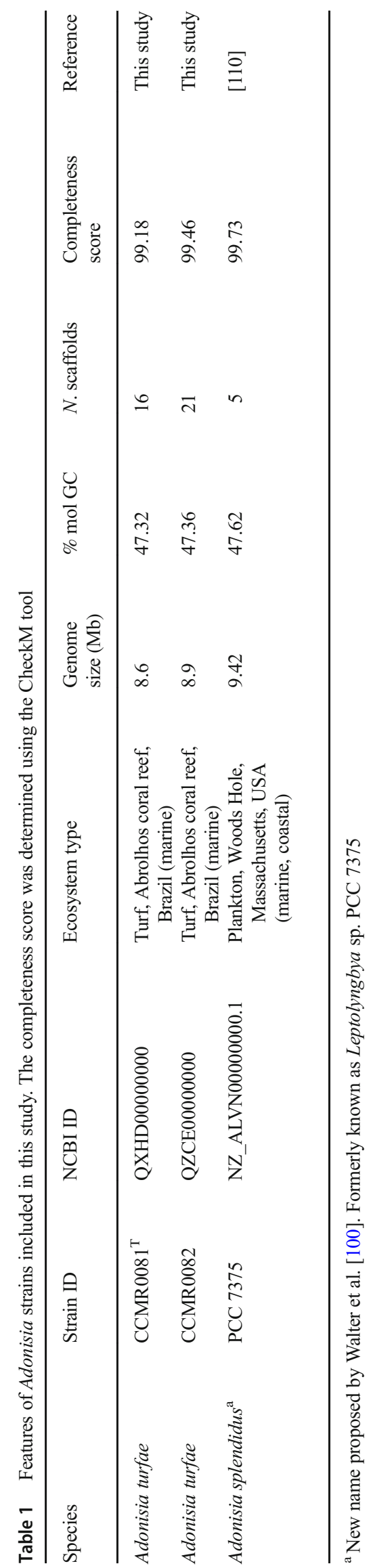

genus/group were used. A total of 28 strains (Fig. S6) were used to infer this phylogeny, due the overlap of the majority matches. The rRNAs were aligned with MAFFT [73] using the -Q-INS- $i$ method, which optimizes the alignment in accordance with the secondary structures of rRNA. Gblocks $0.91 \mathrm{~b}$ $[74,75]$ was used for alignment curation, allowing gap positions within the final blocks. A tree was constructed by the maximum likelihood method using MEGA 6 [76] with default settings, applying a $\mathrm{K} 2+\mathrm{G}+\mathrm{I}$ model of nucleotide substitution, which gave the best fit to this dataset according to the Bayesian Information Criterion (BIC). The support branches of tree topology were checked by 1000 bootstrap replicates. The 16S rRNA gene alignments were used to estimate the degree of genetic distance between strains through the Tajima-Nei method [77].

Thirty-one conserved gene sequences previously validated as phylogenetic markers for (cyano)bacteria [79-80] were used to generate a phylogenomic tree (Fig. 3). These sequences were mined from the genomes using AMPHORA2 tool [81], through default settings for the Bacteria option, and with a cutoff value of $1 . \mathrm{e}^{-10}$. Individual alignments were performed for each of the 31 gene sets through MUSCLE version 3.8 with default settings [82]. All alignments were then concatenated to construct a maximum likelihood tree using RaxML version 7 [83] with Dayhoff + G likelihood model. One thousand bootstrap replications were calculated to evaluate the relative support of the branches. Gloeobacter violaceus PCC 7421 was set as the outgroup in both phylogenies, which were visualized with FigTree version 1.4.2 (Rambaut 2015).

The genomic similarity between the three strains was determined by average amino acid identity (AAI) [84, 85], average nucleotide identity (ANI), dinucleotide signature [86] and in silico DNA-DNA hybridization (DDH) or genometo-genome distance (GGDH) [87-89]. GGDH was compared using the genome-to-genome distance calculator tool, version 2.1 [89] (http://ggdc.dsmz.de/). The Manhattan distances were calculated based on the percentage AAI values of every genome (genome-genome matrix) and was used as the input for making the hierarchical clustering using the hclust() function in $\mathrm{R}$ ( $\mathrm{R} \mathrm{[90]).} \mathrm{This} \mathrm{distance} \mathrm{is} \mathrm{able} \mathrm{to} \mathrm{indicate} \mathrm{how} \mathrm{far/}$ close the genomes are located from each other. The heatmap was produced by the heatmap.2 \{gplots\} package in R, with the background colour of each panel mapping to percentage AAI values.

\section{Chromatic Acclimation Evaluation}

Genomes of model organisms (Fremyella diplosiphon and Geminocystis sp.) were downloaded from NCBI (accession numbers NZ_AP018233 and NZ_AP014815, respectively) and they were annotated in RAST server [91, 92]. Protein sequences related to $\mathrm{CA} 3$ and $\mathrm{CA} 2$ metabolisms (RcaE, RcaC, CpcB1, CpcA1, PcyA, CpeC, CpeD, CpeE, CpeS, 
CpeT, CpeR, CpeB, CpeA, PebA, PebB, RcaF, CpcB2, CpcA2, CpcH2, CpcI2, CpcD2, DpxA, CcaR and CcaS) $[13,15]$ were retrieved from Swissprot and Genbank databases. These sequences were aligned with blast against annotated model genomes in RAST web server to confirm them. A sequence-based comparison was performed in the server between the model organisms and the CCMR0081 ${ }^{\mathrm{T}}$ and CCMR0082 genomes. The results for the known CA2 and CA3 sequences were search in the list of results.

\section{Functional SEED Categories Annotation}

To identify the gene function-relatedness for each genome, we used the first sequence of each cluster of homologous genes generated for the pan-genome as a query for the Diamond tool, version 0.7.9 [93]. Using the SEED database (new release 70 dataset), Diamond created a new database and searched for homology between the query and the SEED database. The homology search was performed for all proteins from the homologous clusters. An e-value of $<1 \mathrm{e}^{-5}$ was considered, and the top hit was defined as the putative function of each cluster. Further, we associated each protein with specific roles and subsystems, i.e. in terms of biological process, molecular function and cellular composition. Combining the related SEED category with the whole pan-genome table yielded the number of each protein in all genomes analysed. Homologues of certain key genes of interest were searched as BLAST queries of homologues from phylogenetically close protein sequences from the NCBI against the entire genome.

\section{Evaluation of Secondary Metabolites}

We used the antiSMASH tool version 3.0.3 [94], to predict the potential secondary metabolite biosynthesis gene clusters. The number of gene clusters for ribosome-dependent peptides, nonribosomal-encoded peptides and polyketide biosynthetic pathways for each analysed genome was generated.

\section{Abundance Profiles}

To estimate the relative abundance of these two genomes (CCMR0081 ${ }^{\mathrm{T}}$ and CCMR0082) across Abrolhos coral reef habitats, their genomes were used as a reference database against the raw reads from 19 turf metagenomes [37] that were sampled in parallel with the cyanobacterial isolation procedure described here. These metagenomes were mapped using Bowtie2 [95] with the -very-sensitive-local and $-a$ options. Correction for ambiguous reads (i.e. those that can be mapped to more than one genome) was performed as described by Iverson et al. [96].

\section{Results}

\section{Growth Measurements and Responses}

The cells were of similar sizes (strain CCMR0081 ${ }^{\mathrm{T}}: 2.4 \pm$ $0.3 \mu \mathrm{m}$ long; $1.3 \pm 0.1 \mu \mathrm{m}$ wide, $N=50$; CCMR0082: $2.7 \pm$ $0.5 \mu \mathrm{m}$ long, $1.3 \pm 0.1 \mu \mathrm{m}$ wide, $N=50$ ) and were arranged in unbranched filaments in $\mathrm{f} / 2$ medium under $50 \mu \mathrm{mol}$ photons $\mathrm{m}^{-2} \mathrm{~s}^{-1}$. In batch cultures without stirring, filaments grew attached to the walls of the flasks or as buoyant, macroscopic agglomerates (Fig. S1). Both strains showed growth from $26{ }^{\circ} \mathrm{C}$ to at least $28{ }^{\circ} \mathrm{C}$, with limited growth at $30{ }^{\circ} \mathrm{C}$ (Fig. S2). The maximum growth rates of strains CCMR0081 ${ }^{\mathrm{T}}$ $\left({ }^{\mathrm{T}}\right.$ denotes the type strain of the novel species) and CCMR0082 were 0.15 and 0.08 day $^{-1}$ (Fig. S2), representing generation times of 8.6 and 4.5 days, respectively. The strain CCMR $0081^{\mathrm{T}}$ showed higher growth rates than strain CCMR0082 at 24, 26 and $28{ }^{\circ} \mathrm{C}$. Slight growth at $30^{\circ} \mathrm{C}$. Both strains grew slightly faster at $26^{\circ} \mathrm{C}$ compared to 24 and $28{ }^{\circ} \mathrm{C}$. Coincidently, the seawater temperature in the Abrolhos reefs is $26^{\circ} \mathrm{C}$ on average, reaching maximum values $\left(\sim 28^{\circ} \mathrm{C}\right)$ only in summer months [97].

Regarding the optical properties, the in vivo absorption spectra of the two cyanobacterial strains were very similar (Fig. 1a), with a strong peak corresponding to phycoerythrin at 550-552 $\mathrm{nm}$ and the typical peaks of chlorophyll $a(\mathrm{Chl} a)$ in the blue $(436 \mathrm{~nm})$ and red $(676 \mathrm{~nm})$ regions of the spectrum. The absorption at $630 \mathrm{~nm}$ is typical of PC. The chlorophyll $a$ contents were $119 \pm 8$ and $591 \pm 34 \mu \mathrm{g} \mathrm{g} \mathrm{wet} \mathrm{weight}^{-1}$ for strains CCMR0081 ${ }^{\mathrm{T}}$ and CCMR0082, respectively. The phycobiliprotein (phycocyanin (PC) and phycoerythrin (PE)) contents were $6323 \pm 461$ and $9256 \pm 743 \mu \mathrm{g} \mathrm{g}_{\text {wet weight }}{ }^{-1}$ for strain CCMR0081 ${ }^{\mathrm{T}}$ and CCMR0082, respectively. Phycoerythrin was the dominant phycobiliprotein in both strains $\left(41 \pm 6 \%\right.$ for strain CCMR008 $1^{\mathrm{T}}$ and $64 \pm 1 \%$ CCMR0082). The phycobiliprotein/chlorophyll ratios ranged from $54 \pm 7$ for strain $C C M R 0081^{\mathrm{T}}$ to $15 \pm 7$ for strain CCMR0082.

As shown in Fig. $1 \mathrm{~b}$ and c, the two cell types presented similar absorption peaks when cultivated under white light, such as Chla at 437 and $678 \mathrm{~nm}$, carotenoids at $450-530 \mathrm{~nm}, \mathrm{PE}$ at $567 \mathrm{~nm}$ and $\mathrm{PC}$ at approximately $620 \mathrm{~nm}$. Indeed, in white light, CCMR0081 ${ }^{\mathrm{T}}$ and CCMR0082 cells are red/brownish in colour due to accumulation of PE. We identified the presence of the photoacclimation response for both Adonisia strains. Whereas CCMR0081 ${ }^{\mathrm{T}}$ has been experimentally demonstrated to perform chromatic acclimation type 3 (CA3) regulating both $\mathrm{PC}$ and $\mathrm{PE}, \mathrm{CCMR} 0082$ strain show to be under chromatic acclimation type 2 (CA2) altering PE but no PC (Fig. 1b, c). Rather than showing unique forms of CA, the two Abrolhos cyanobacteria have forms of CA that are known from the 1970s (97-99). 
Fig. 1 Optical and absorption

a spectra for Adonisia turfae strains. a Optical characteristics of strains $\mathrm{CCMR} 081^{\mathrm{T}}$ and CCMR0082. In vivo absorption spectra from 400 to $700 \mathrm{~nm}$ of both strains grown under the same irradiance $\left(50 \mu \mathrm{E} \mathrm{m}^{-2} \mathrm{~s}^{-1}\right.$; white light; $16 / 8$ light/dark cycle) and temperature $\left(24^{\circ} \mathrm{C}\right)$. Cells were harvested from a 7-day-old culture. The spectra were normalized to the blue absorption peak of chlorophyll $a$. Both strains showed strong absorbance in the $\mathrm{PE}$ region $(550-552 \mathrm{~nm}) . \mathbf{b}, \mathbf{c}$ Comparison of the absorption spectra of A. turfae CCMR0081 ${ }^{\mathrm{T}}$ (b) and CCMR0082 (c) cells grown in white light (WL, solid black line), far-red light (FRL, dotted black line) and dark conditions (DK, dotted grey line)
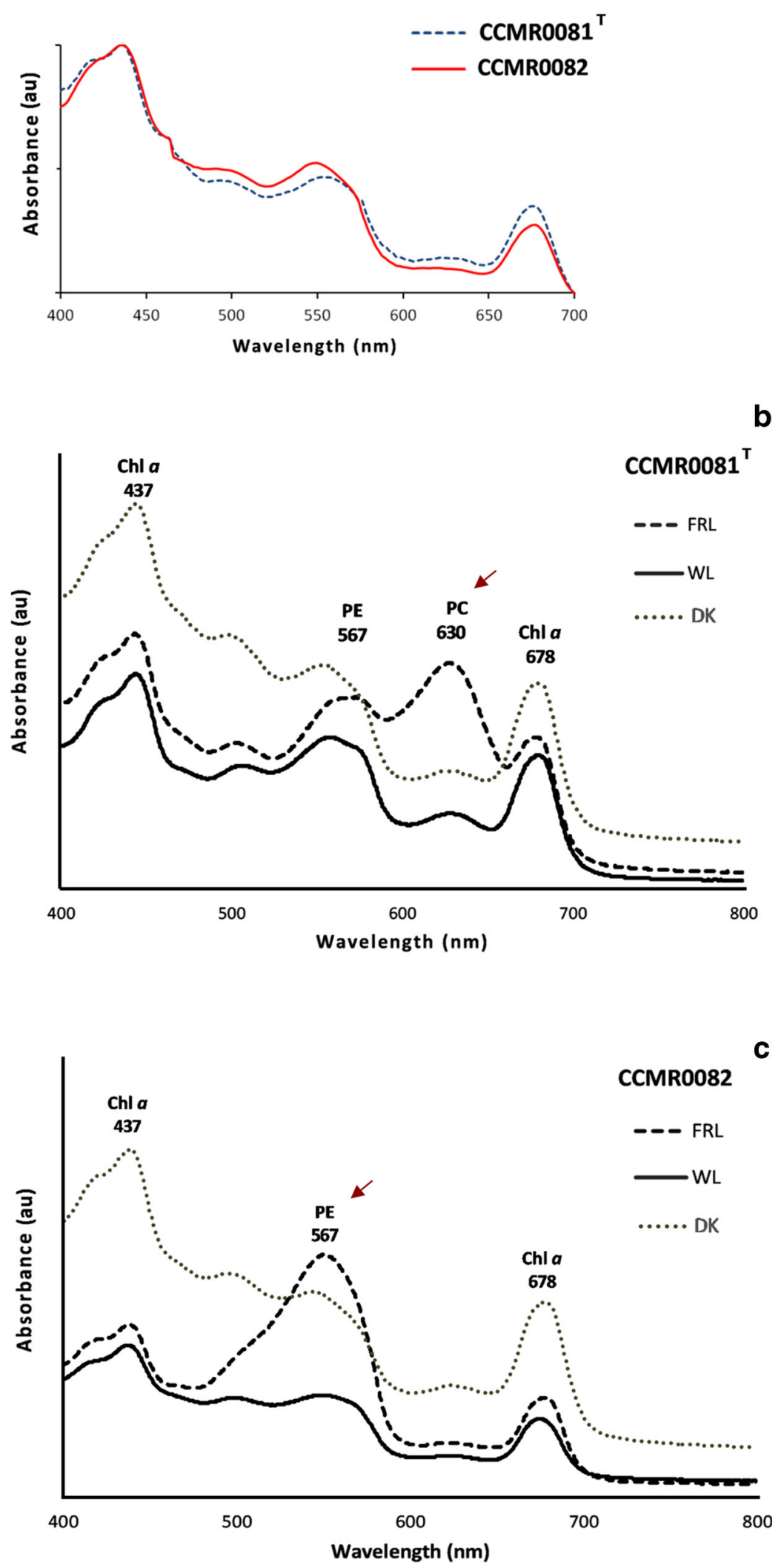
We tested both strains for hydrogen $\left(\mathrm{H}_{2}\right)$ production and nitrogen $\left(\mathrm{N}_{2}\right)$ fixation estimation. They showed $\mathrm{H}_{2}$ production in argon and nitrogen atmosphere conditions (Fig. S3). In a nitrogen atmosphere, CCMR008 $1^{\mathrm{T}}$ showed its highest $\mathrm{H}_{2}$ production earlier (14 days, $1.8 \mathrm{nmol} \mathrm{H}_{2} \mathrm{~g}^{-1} \mathrm{DW}$ ) than CCMR0082 (21 days, $1.81 \mathrm{nmol} \mathrm{H} \mathrm{g}^{-1} \mathrm{DW}$ ), while in an argon atmosphere, CCMR0082 produced greater amounts of $\mathrm{H}_{2}$ than CCMR0081 ${ }^{\mathrm{T}}$ (both in 21 days) (Fig. S3). Using the 1:4 ratio of $\mathrm{H}_{2}$ produced to $\mathrm{N}_{2}$ fixed reported for Trichodesmium [53], we estimated a nitrogen fixation rate of $7.2 \mathrm{nmol} \mathrm{N}_{2}$ fixed $\mathrm{g}^{-1} \mathrm{DW}$ for both CCMR0081 ${ }^{\mathrm{T}}$ and CCMR0082.

\section{Whole-Genome Sequences and Phylogenomic Assignment}

A total of 7.2 million reads for CCMR0081 ${ }^{\mathrm{T}}(150 \times$ coverage $)$ and 5.7 million reads for CCMR0082 (136× coverage) were obtained. Two genome maps were obtained by binning based on tetranucleotide frequency with ESOM, revealing CCMR0081 ${ }^{\mathrm{T}}$ co-cultured with other microbial strain and CCMR0082 virtually pure (Fig. S4). The nearly complete genome sequences of the two new filamentous cyanobacteria were assembled, and the basic statistics were obtained (Tables 1 and S1). Completeness is above 99\% for both genomes and contamination is 1.36 and $1.19 \%$ for CCMR0081 ${ }^{\mathrm{T}}$ and CCMR0082 genomes, respectively. CCMR0081 ${ }^{\mathrm{T}}$ has a genome size of $8.6 \mathrm{Mb}$ (average GC content of $47.3 \%$ ) assembled into 16 contigs, while CCMR0082 has a genome size of $8.9 \mathrm{Mb}$ (average GC content of $47.36 \%$ ) assembled into 21 contigs (Fig. 2a). The genome size of their closest relative, Adonisia splendidus $\mathrm{PCC} 7375^{\mathrm{T}}$ [100], is $9.42 \mathrm{Mb}$ (average GC content of $47.6 \%$ ). The numbers of predicted proteincoding genes were 7276 and 7713 for CCMR0081 $1^{\mathrm{T}}$ and CCMR0082, respectively, while there were a total of 59 and 58 tRNAs (PCC $7375^{\mathrm{T}}$ has 63 tRNAs), 6 and 4 16S rRNAs (PCC $7375^{\mathrm{T}}$ has 9 rRNAs), and 16 and 11 other rRNAs, respectively. The last group included 1 transfer messenger (tmRNA) for each genome. Both cyanobacterial genomes showed over $99 \%$ completeness, as does that of PCC $7375^{\mathrm{T}}$. GC skew analysis assessed the predicted origin and terminator of DNA replication in CCMR0081 ${ }^{\mathrm{T}}$ and CCMR0082 (Fig. S5).

The phylogenomic assignment, the AAI and GGD between CCMR0081 ${ }^{\mathrm{T}}$ and CCMR0082 were 97 and 95.2\%, respectively, whereas AAI and GGD values between both strains and the closest relative, $\mathrm{PCC} 7375^{\mathrm{T}}$, was 92 and $65 \%$, respectively. (Fig. 2b). The species ( $\geq 95 \%$ AAI and $\geq 70 \%$ GGD) and genus $(\geq 70 \% \mathrm{AAI})$ cutoff delimitations indicate that CCMR0081 ${ }^{\mathrm{T}}$ and CCMR0082 belong to the same species, while $\mathrm{PCC} 7375^{\mathrm{T}}$ is another species Adonisia splendidus. The phylogenomic reconstruction based on 31 conserved protein sequences demonstrated that the CCMR $0081^{\mathrm{T}}$ and CCMR0082 share $99 \%$ identity with each other and only 94\% identity with their closest phylogenetic neighbour,
PCC $7375^{\mathrm{T}}$ (Fig. 3). The $16 \mathrm{~S}$ rRNA sequence similarity between CCMR0081 ${ }^{\mathrm{T}}$ and CCMR0082 was $100 \%$ and that of both with PCC $7375^{\mathrm{T}}$ was $99 \%$ (Fig. S6). Therefore, there is sufficient genomic and phylogenetic evidence to propose the creation of a new species within the genus Adonisia to encompass these two strains isolated from turfs. The proposed name is Adonisia turfae (Dataset S1).

The functional roles for the Adonisia spp. genomic sequences were categorized (Fig. S7) and the photosynthetic potential of two Adonisia turfae strains was analysed (Fig. S8A-B). Genomic analysis confirmed the presence of genes encoding RcaE photosensor, as well as RcaF and RcaC regulators of $\mathrm{PC}$ and $\mathrm{PE}$ components for $\mathrm{CA} 3$, while we found $\mathrm{CcaS}$ photosensor and $\mathrm{CcaR}$ regulator of $\mathrm{PE}$ components for CA2 (Table S2).

In addition, genes related to light-harvesting phycobilisomes were abundant in CCMR0081 ${ }^{\mathrm{T}}(N=50)$ and CCMR0082 $(N=$ 36 ), including the $\alpha, \beta$ subunits, the linker gene of phycoerythrin $\left(N=19\right.$ for CCMR0081 ${ }^{\mathrm{T}}$ and $N=16$ for CCMR0082), and the $\alpha, \beta$ subunits and small rod linker gene of phycocyanin ( $N=18$ for CCMR0081 ${ }^{\mathrm{T}} ; N=9$ for CCMR0082). The uptake and utilization of nitrogen, phosphate and iron were detected (Fig. S8C). In total, 84 and 73 genes involved in phosphate metabolism were identified in CCMR0081 ${ }^{\mathrm{T}}$ and CCMR0082, respectively (Fig. S8C). The genetic machinery responsible for cellular phosphate incorporation includes alkaline phosphatase genes and the supplementary genes for the functioning of the pho regulon. The uptake and utilization of nitrogen source genes nif $\mathrm{B}, n i f \mathrm{H}, n i f \mathrm{~S}, n i f \mathrm{~T}, n i f \mathrm{U}, n i f \mathrm{~W}, n i f \mathrm{X}$ and $n i f \mathrm{Z}$ were also present (Fig. S8). For iron metabolism, 32 genes were identified in CCMR0081 ${ }^{\mathrm{T}}$, and 29 genes in CCMR0082, compared to only 15 genes in $\mathrm{PCC} 7375^{\mathrm{T}}$. Sequences related to the chemotaxis regulator $(\mathrm{CheY})(N=21)$ and other chemotaxis-involved genes (che $\mathrm{W}-\mathrm{V}$, che A, che $\mathrm{B}$, che $\mathrm{R}$ ) were found in both strains. The type IV pilus/fimbrial assembly and prepilin peptidase

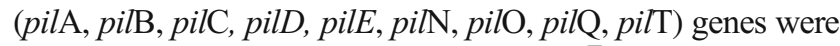
also found in both genomes. CCMR0081 ${ }^{\mathrm{T}}$ and CCMR0082 possess chemotaxis-related genes, including the genetic machinery encoding the CheA-CheY signal transduction pathway coupled to flagella rotation or pili extension, attachment and retention. Top-30 homologous proteins for CCMR0081 ${ }^{\mathrm{T}}$, CCMR0082 and PCC $7375^{\mathrm{T}}$ are indicated in Table S1. Adonisia turfae strains CCMR0081 ${ }^{\mathrm{T}}$ and CCMR0082 have multiple predicted genes coding secondary metabolites, ranking them among the highest within the cyanobacteria in this regard $[20,78]$. While most cyanobacteria contain an average of five NRPS/PKS clusters per genome (approximately $5 \%$ of cyanobacterial genomes) [78], CCMR0081 ${ }^{\mathrm{T}}$ and CCMR0082 genomes possess an average of 15 clusters. The two strains present more NRPS/PKS gene clusters than their closest phylogenetic relatives, but $A$. turfae shows a lower number of clusters than Moorea producens PAL15AUG08-1, recognized as the most prolific in terms of secondary metabolite potential 
Fig. 2 Whole-genome comparison. a Whole-genome identity map generated using the Cgview comparison tool. Protein sequences of each strain were compared against the M. producens PAL genome with blastx. The reference used was the major genome assembled in one contig. Rings from outermost to innermost represent (1) CCMR0081 ${ }^{\mathrm{T}}$ genes; (2) CCMR0082 genes; (3) PCC7375 ${ }^{\mathrm{T}}$ genes; (4) G+C Content; (5) G+C Skew. b Values of AAI, ANI and GGD presented in a matrix format

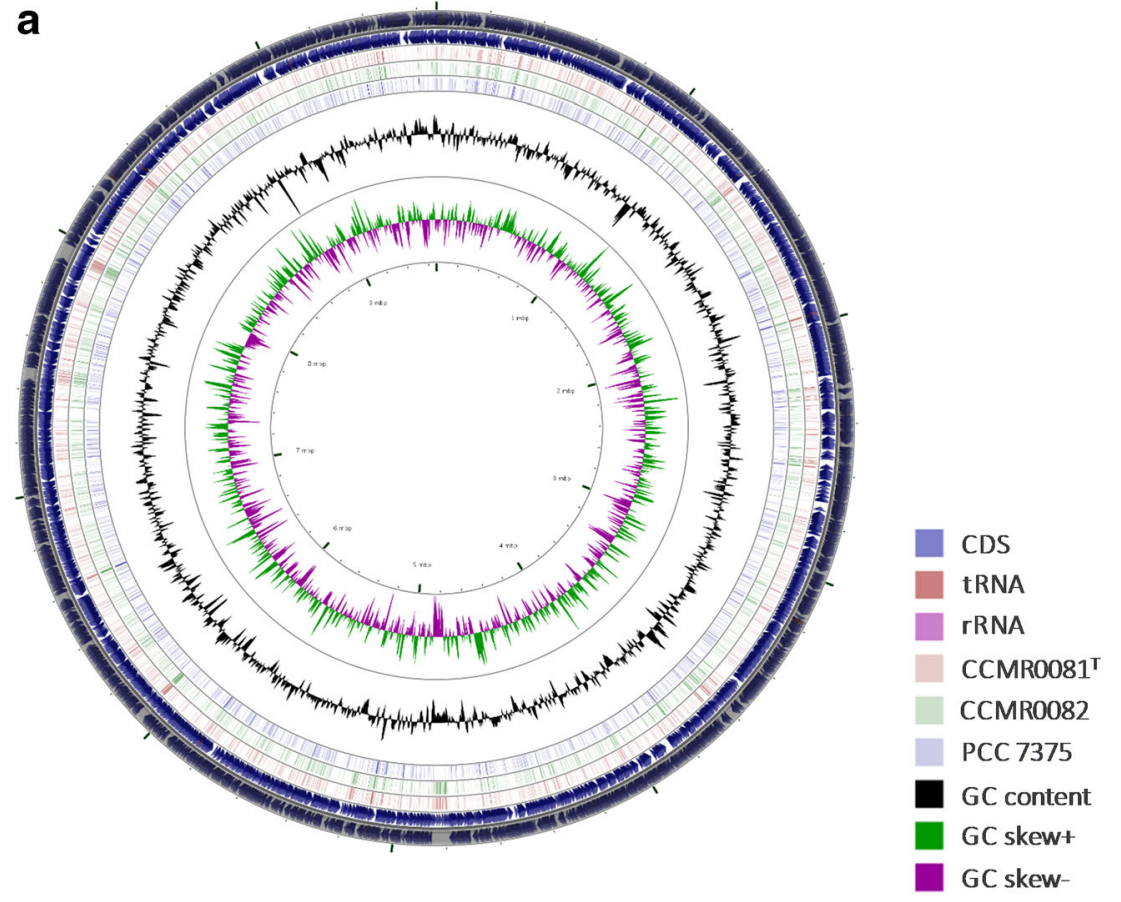

b

\begin{tabular}{lcccc}
\hline \multicolumn{5}{c}{ AAl / ANI / GGD } \\
\hline \\
\hline CCMR0081 $^{\top}$ & CCMR0081 $^{\top}$ & CCMR0082 & PCC 7375 & Pal \\
CCMR0082 $^{100 / 100 / 100}$ & $97 / 98.9 / 95.2$ & $92 / 95.2 / 65.3$ & $75.1 / 54.6 / 28.4$ \\
PCC 7375 & & $100 / 100 / 100$ & $92 / 95.1 / 65.1$ & $75.1 / 54.1 / 27.6$ \\
Pal & & $100 / 100 / 100$ & $74 / 54.4 / 28.2$ \\
\hline
\end{tabular}

[20]. Genes encoding components of the polyketides synthase (PKS, mainly Type I) and nonribosomal peptide synthase (NRPS) biosynthetic pathways were the most abundant in the genomes of the isolates from turfs (Fig. 4). Genes encoding polyketides, nonribosomal peptides, terpenes, bacteriocins, cyanobactins, lassopeptides and arylpolyenes were found in the strains CCMR0081 $1^{\mathrm{T}}$ and CCMR0082. CCMR0081 ${ }^{\mathrm{T}}$ and CCMR0082 exhibit approximately three-fold more PKS and approximately seven-fold more hybrid NRPS/PKS than PCC $7375^{\mathrm{T}}$. CCMR0081 ${ }^{\mathrm{T}}$ presents 24 gene clusters, including seven PKS and eight hybrids (PKS/NRPS) (Fig. 4). Compared to a diverse panel of previously examined cyanobacterial genomes [20, 78], CCMR0081 ${ }^{\mathrm{T}}$ and CCMR0082 rank 4th and 8th among the cyanobacteria with the greatest numbers of NRPS/PKS clusters (Fig. 4).

\section{Abundance of Adonisia turfae Across Turf Metagenomes}

The two Adonisia turfae genomes accounted for a significant portion of the analysed turf metagenomes (Fig. S9). Reads from the two genomes were widespread among the metagenomes (ranging from an average of $\sim 1$ to $15 \%$ ) and were more abundant in the metagenomes from the Pedra de Leste (PL) and Archipelago (AR) sites than that from the Parcel dos Abrolhos (PAB) site. Incidentally, the two A. turfae strains were isolated from assemblages growing at the Archipelago site. Metagenomes from reefs closest to the shore (PL and AR) exhibited concentration of the highest number of hits in both genomes (Fig. S9). These results suggest that $A$. turfae was widely distributed across the Abrolhos reefs. The number of shared genes between CCMR0081 ${ }^{\mathrm{T}}$, CCMR0082 and the turf metagenomes is 1055 in total (Fig. S10).

The coverage of each genome in all Abrolhos turf metagenomes was plotted using genome coverage by position. Although some genome regions have high coverage, reads from the entire genome of both strains match those in metagenomes samples (Fig. S11).

\section{Discussion}

\section{Ecogenomics of Adonisia turfae}

The formation of turf is an important phenotype displayed by these cyanobacteria. Turfs are among the most successful 


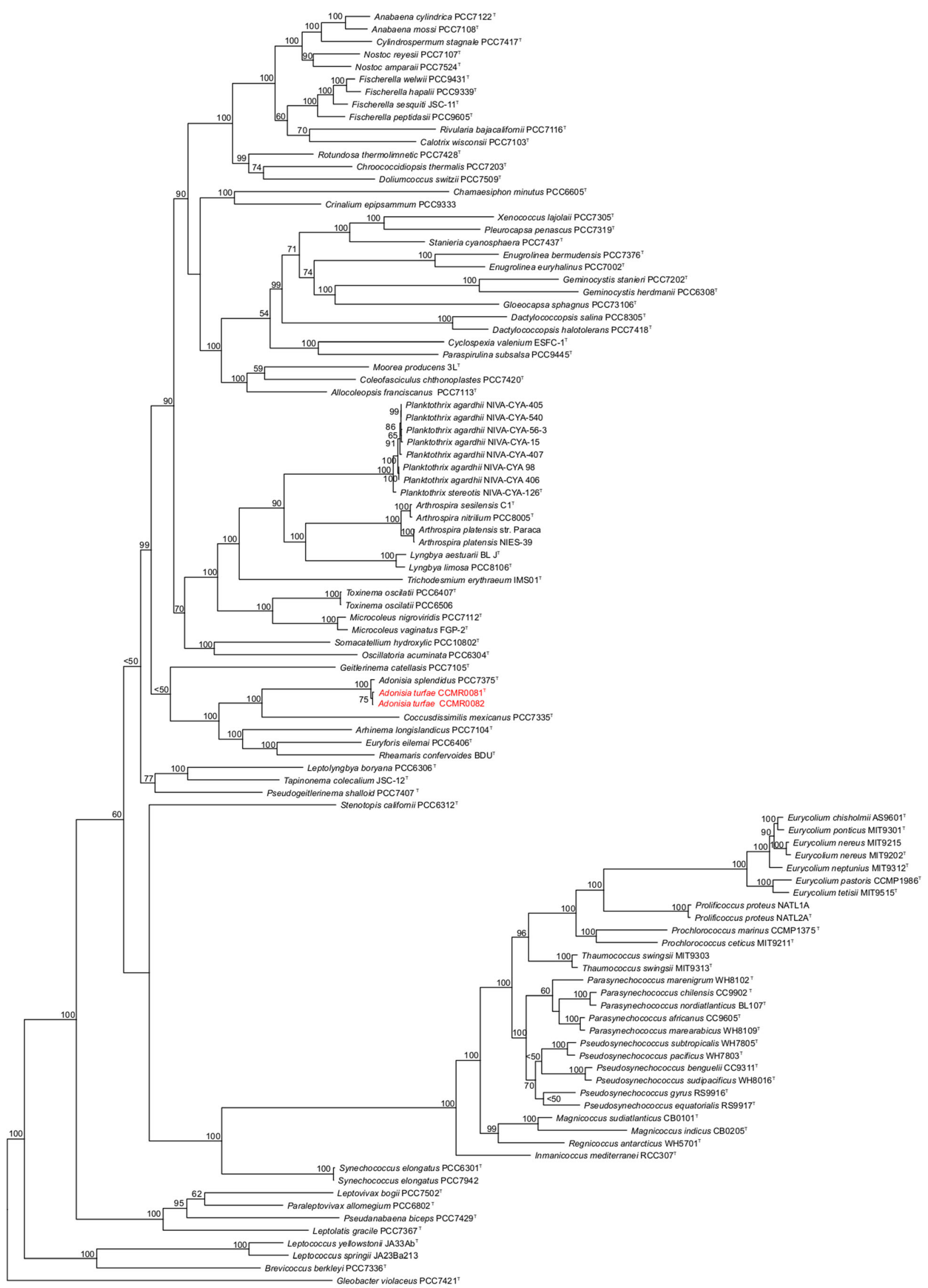


Fig. 3 Position of Adonisia turfae strains within the cyanobacteria phylum. The multigene tree reconstruction was built through maximum likelihood using the Dayhoff $+\mathrm{G}$ likelihood model with the RaxML tool. Phylogeny was inferred from a set of conserved marker genes of 102 genomes. The numbers at the nodes indicate bootstrap values as percentages greater than $50 \%$. Bootstrap tests were conducted with 1000 replicates. The unit of measure for the scale bars is the number of nucleotide substitutions per site. The genus and species names adopted in this tree were according to Walter et al. [100]. The Gloeobacter violaceus PCC 7421 sequence was designated as an outgroup

benthic components of reef systems [101]. The genomes, growth rates and pigments analysed in the present study hint at several possible roles performed by the cyanobacteria in turfs. The genomes of Adonisia CCMR0081 ${ }^{\mathrm{T}}$ and CCMR0082 are among the largest known cyanobacterial genomes. Unicellular cyanobacteria such as Prochlorococcus exhibit reduced genomes $(1.7 \mathrm{Mb})$, while filamentous cyanobacteria such as Scytonema sp. exhibit large genomes (>10 Mb) [102, 103]. Prokaryotes with larger genomes tend to present higher phenotypic and physiologic plasticity and wide niche occupancy [104-107]. The genomic taxonomy and phylogenomic analyses allowed us to place both genomes within a new Adonisia apecies. Strains CCMR0081 ${ }^{\mathrm{T}}$ and CCMR0082 belong to the same species because they share at least $98.8 \%$ 16S rRNA gene sequence similarity, 95\% of AAI and 70\% GGD [85, 108, 109]. They belong as a separate species in the genus Adonisia [100] because they share 95\% ANI, 92\% AAI and only 65\% GGD with Adonisia splendidus PCC $7375^{\mathrm{T}}$.

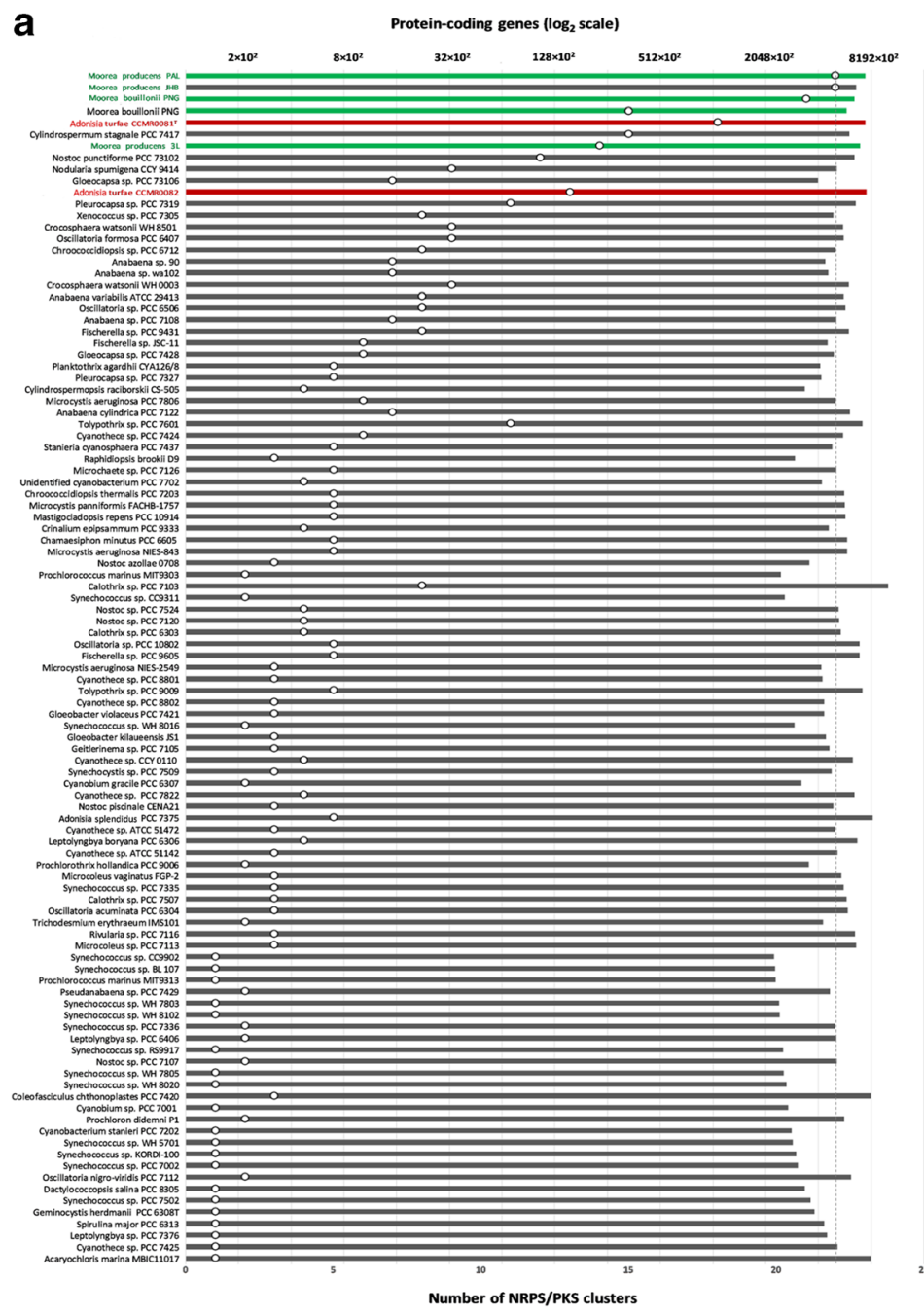

b

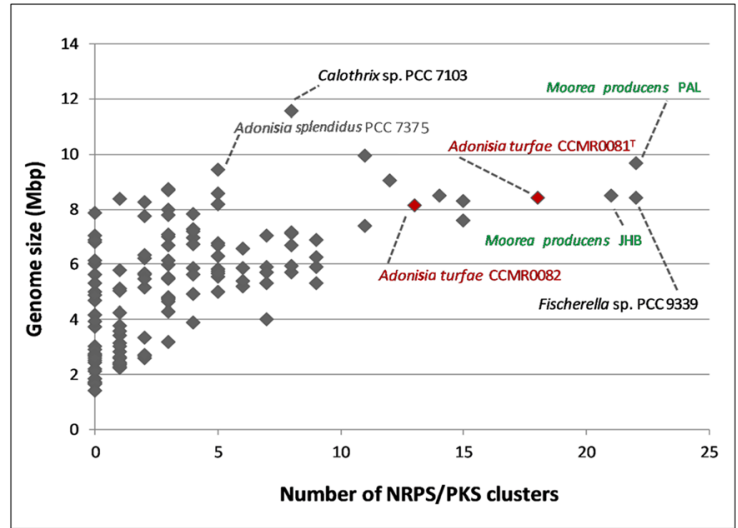

Fig. 4 Distribution of secondary metabolites across cyanobacteria. Occurrence of the nonribosomal-encoded peptide synthase (NRPS), polyketide synthase (PKS) and hybrid NRPS/PKS biosynthetic pathways. Distribution of the nonribosomal-encoded peptide (NRPS) and polyketide biosynthetic pathways (PKS) in cyanobacteria. a The occurrence represents the relationships between NRPS/PKS gene clusters versus protein-coding gene numbers ( $\log _{2}$ scale). b Relationship between the total number of NRPS/PKS gene clusters and

bacterial genome size. Data for cyanobacterial genomes were retrieved from Shih et al. [78] $(N=126)$ and Leao et al. [20] $(N=54)$ and compared with both genomes reported here. The corresponding name and details of each strain were maintained according to Shih et al. [78] and Leao et al. [20]. The positions of the CCMR0081 $1^{\mathrm{T}}$ and CCMR0081 genomes are indicated with red, whereas Moorea species are highlighted in green colour. A total of 52 genomes lacked the analysed NRPS/PKS gene clusters, and they are not displayed in this graph 


\section{Photo Acclimation Response in Adonisia}

The natural environment imposes differences in light availability and cyanobacteria have evolved various photoacclimation processes for photosynthesis and growth $[11,12-14]$. Whereas CCMR $0081^{\mathrm{T}}$ has been experimentally demonstrated to perform $\mathrm{CA} 3$ regulating both $\mathrm{PC}$ and $\mathrm{PE}$, CCMR0082 strain shown to be under CA2 altering PE but nor PC. Chromatic acclimation responses are widely reported photoacclimation strategies of cyanobacteria [11, 12-14]. Genomic analysis confirmed the presence of genes encoding $\mathrm{RcaE}$ photosensor, as well as $\mathrm{RcaF}$ and $\mathrm{RcaC}$ regulators of $\mathrm{PC}$ and PE components for CA3, while we found CcaS photosensor and $\mathrm{CcaR}$ regulator of $\mathrm{PE}$ components for $\mathrm{CA} 2$ (Table S2) [110-112] .

In addition, regulation of the expression of phycobilisomepigmented proteins (rod linkers of the light-harvesting antennae proteins phycoerythrin and phycocyanin) may be mediated by cpe genes present in the genomes of the two strains. Differences in PC-related genes between the two strains are expected since the existence of multiple phycocyanin types is found in cyanobacteria which chromatically acclimate by modulating the synthesis of both phycocyanin and phycoerythrin [112, 113]. Although, this is not true for cyanobacteria which chromatically acclimate by modulating the synthesis of phycoerythrin alone [112]. Variations in colour (red and bluegreen) have been observed in filaments of these two cyanobacteria in the turfs of the Abrolhos reefs and in cultures (Fig. S1) [17]. As the spectral properties of the light that cells are exposed to in low versus high density cultures change with time, it is likely to induce a switch from PE-containing phycobilisomes to $\mathrm{PC}$-containing phycobilisomes as the green to red light ratio in the culture changes [114]. Change to a green phenotype due to phycobilisome degradation $(\mathrm{N}$ storage) cannot be confirmed in the present study.

Under far-red light condition, Adonisia turfae CCMR0081 ${ }^{\mathrm{T}}$ and CCMR0082 showed PE and PC synthesis alteration (Fig. 1b, c). Recently, far-red photoacclimation (FaRLiP) strategy has been found in more cyanobacteria, e.g. Leptolyngbya JSC-1 [115] and Synechococcus sp. PCC 7335 [12]. However, specific genes involved in growth under far-red light $[115,116]$, including synthesis of Chls $f$ and $d$, were not found in CCMR0081 ${ }^{\mathrm{T}}$ and CCMR0082 genomes. The most plausible explanation is that CA responses are due to leakage from the far-red light that is activating the red light response. Analysis of metagenomes corresponding to a wide area of the Abrolhos reefs and two different seasons [37] revealed a vast spatial distribution, persistence and high relative abundance contribution of Adonisia turfae genomes in turfs across this important coral reef ecosystem in the South Atlantic Ocean. The wide occurrence of A. turfae along a $50-\mathrm{km}$ cross-shelf gradient highlights the ability of this cyanobacterium to colonize benthic substrates over a vast range of environmental physical and chemical gradients (e.g. irradiance, temperature and nutrient levels). Such relatively high physiological plasticity is in agreement with the rich physiological and genomic repertoires described herein for the species, which include potential for chromatic acclimation, nitrogen fixation, secondary metabolite production and growth at relatively high temperatures. Abrolhos corals and Symbiodinium exhibit optimum growth at temperatures below $26^{\circ} \mathrm{C}$ [117], whereas the cyanobacteria studied here are able to grow at $28^{\circ} \mathrm{C}$, with maximum growth at $30^{\circ} \mathrm{C}$. Cyanobacterial turfs are increasing in Abrolhos as well as in other reef systems worldwide [39]. Direct positive effects of physical and chemical environmental factors (e.g. temperature and nutrients) on cyanobacterial growth are often evoked as the underlying mechanism for this observed expansion of turfs, combined with indirect factors that reduce coral coverage (e.g. infectious diseases that open up niches for turf and macroalgal colonization) [118]. Despite the relatively low growth rates (doubling times up to 9 days) under light and temperature levels representative of their natural environment, in Abrolhos, the new Adonisia turfae strains can clearly grow in a wide range of temperature and light conditions. The high abundance and diversity of secondary metabolite genes revealed in this cyanobacterium also reflect its ecological success in the Abrolhos reefs. Secondary metabolite genes are involved in important ecological processes in cyanobacteria, such as signalling pathways, quorum sensing, resource competition through allelopathy, feeding deterrence and UV protection [9, 10, 119-121]. Moreover, these metabolites include various bioactive compounds known to negatively influence coral health [38, 122-124]. The persistence and abundance of a species in its environment are ultimately determined by the balance between gain and loss factors. Herbivorous fish and small invertebrates are common members of reef systems [101], representing potential loss factors for cyanobacterial turfs. Thus, any increased grazing deterrence capability due to high production of secondary metabolites may confer the necessary competitive advantage for the establishment and spreading of these microbial assemblages.

Cyanobacteria are a dominant group of organisms in the turf metagenomes. Up to $71 \%$ of the metagenomic sequences belonged to Cyanobacteria [37]. We demonstrate here that both strains CCMR0081 ${ }^{\mathrm{T}}$ and CCMR0082 are present and contribute to the functional composition of Abrolhos turfs. A long-term study (2006-2016) of the Abrolhos benthos determined that cyanobacteria (turfs) were the best predictors of coral growth deterioration [125]. In addition, Symbiodinium from Mussismilia braziliensis corals confronted with turfforming cyanobacterial exudates showed a negative effect of the exudates on the symbionts, suggesting a possible role for cyanobacteria in coral tissue toxicity and necrosis. 


\section{Conclusions}

High abundance and diversity of potential enzymes encoding components of secondary metabolite biosynthesis, chromatic acclimation strategies CA2 and CA3, and high temperature tolerance are the most distinct characteristics of Adonisia turfae. Based on its genomic characteristics and basic physiological traits, we hypothesise that $A$. turfae contributes to the success of turfs in the reef system due to its high potential to produce secondary metabolites, its wide distribution in turfs metagenomes and its ability to grow at high temperatures. A diverse secondary metabolite genetic repertoire might help to prevent the whole assemblage from being heavily impacted by grazers and may allow these cyanobacteria to inhibit the growth of competing benthic organisms by means of toxin production.

Accession Number The Whole Genome Shotgun Project for CCMR0081 ${ }^{\mathrm{T}}$ was deposited in GenBank under accession number QXHD00000000 (Bioproject: PRJNA484501), while for CCMR0082 was deposited in GenBank under accession number QZCE00000000 (Bioproject: PRJNA487318).

Acknowledgements The sequence data selected from the GEBA database (Accession number 2509601039) and used in this paper was produced by the US Department of Energy Joint Genome Institute (http:// www.jgi.doe.gov/) in collaboration with the user community.

Funding Information The authors acknowledge CNPq, CAPES and FAPERJ for their financial support for this study. JMW thank CNPq (207751-2014/5) and CAPES for the fellowships.

\section{Compliance with Ethical Standards}

Conflict of Interest The authors declare that they have no conflict of interest.

Field Study Permissions The following information was supplied relating to field study approvals: sampling permit SISBIO no. 27147-2 issue by the Ministry of Environment Institute Chico Mendes (ICMBio).

\section{References}

1. Garcia-Pichel F, Belnap J, Neuer S, Schanz F (2003) Estimates of global cyanobacterial biomass and its distribution. 213-227. https://doi.org/10.1127/1864-1318/2003/0109-0213

2. Luque I, Zabulon G, Contreras A, Houmard J (2001) Convergence of two global transcriptional regulators on nitrogen induction of the stress-acclimation gene nblA in the cyanobacterium Synechococcus sp. PCC 7942. Mol Microbiol 41:937-947. https://doi.org/10.1046/j.1365-2958.2001.02566.x

3. Muramatsu M, Hihara Y (2012) Acclimation to high-light conditions in cyanobacteria: From gene expression to physiological responses. J Plant Res 125:11-39. https://doi.org/10.1007/ s10265-011-0454-6

4. Watanabe M, Semchonok DA, Webber-Birungi MT, Ehira S, Kondo K, Narikawa R, Ohmori M, Boekema EJ, Ikeuchi M (2014) Attachment of phycobilisomes in an antenna-photosystem
I supercomplex of cyanobacteria. Proc Natl Acad Sci U S A 111: 2512-2517. https://doi.org/10.1073/pnas.1320599111

5. Waterbury JB, Watson SW, Guillard RRL, Brand LE (1979) Widespread occurrence of a unicellular, marine, planktonic, cyanobacterium. Nature 277:293-294. https://doi.org/10.1038/ 277293a0

6. Capone DG, Zehr JP, Paerl HW, Bergman B, Carpenter EJ (1997) Trichodesmium, a Globally Significant Marine Cyanobacterium. Science 276:1221-1229. https://doi.org/10.1126/science.276. 5316.1221

7. Dupraz C, Reid RP, Braissant O, Decho AW, Norman RS, Visscher PT (2009) Processes of carbonate precipitation in modern microbial mats. Earth Sci Rev 96:141-162. https://doi.org/10. 1016/j.earscirev.2008.10.005

8. Kaplan A, Weiss G, Sukenik A (2016) Cyanobacterial secondary metabolites mediate interspecies-intraspecies communication in the water body: Talking in the water body. Environ Microbiol 18:305-306. https://doi.org/10.1111/1462-2920.12922

9. Micallef ML, D'Agostino PM, Al-Sinawi B, Neilan BA, Moffitt MC (2014) Exploring cyanobacterial genomes for natural product biosynthesis pathways. Mar Genomics 21:1-12. https://doi.org/ 10.1016/j.margen.2014.11.009

10. Nagle D, Paul V (1999) Production of secondary metabolites by filamentous tropical marine cyanobacteria: ecological functions of the compounds. J Phycol 35:1412-1421. https://doi.org/10.1046/ j.1529-8817.1999.3561412.x

11. Grébert T, Doré H, Partensky F, Farrant GK, Boss ES, Picheral M, Guidi L, Pesant S, Scanlan DJ, Wincker P, Acinas SG, Kehoe DM, Garczarek L (2018) Light color acclimation is a key process in the global ocean distribution of Synechococcus cyanobacteria. Proc Natl Acad Sci U S A 115:E2010-E2019. https://doi.org/10.1073/ pnas. 1717069115

12. Ho M-Y, Gan F, Shen G, Bryant DA (2017) Far-red light photoacclimation (FaRLiP) in Synechococcus sp. PCC 7335. II.Characterization of phycobiliproteins produced during acclimation to far-red light. Photosynth Res 131:187-202. https://doi.org/ 10.1007/s11120-016-0303-5

13. Hirose Y, Misawa N, Yonekawa C, Nagao N, Watanabe M, Ikeuchi M, Eki T (2017) Characterization of the genuine type 2 chromatic acclimation in the two Geminocystis cyanobacteria. DNA Res 24:387-396. https://doi.org/10.1093/dnares/dsx011

14. Hirose Y, Chihong S, Watanabe M, Yonekawa C, Murata K, Ikeuchi M, Eki T (2019) Diverse Chromatic Acclimation Processes Regulating Phycoerythrocyanin and Rod-Shaped Phycobilisome in Cyanobacteria. Mol Plant 12:715-725. https:// doi.org/10.1016/j.molp.2019.02.010

15. Wiltbank LB, Kehoe DM (2019) Diverse light responses of cyanobacteria mediated by phytochrome superfamily photoreceptors. Nat Rev Microbiol 17:37-50. https://doi.org/10.1038/ s41579-018-0110-4

16. Malinsky-Rushansky N, Berman T, Berner T, Yacobi YZ, Dubinsky Z (2002) Physiological characteristics of picophytoplankton, isolated from Lake Kinneret: responses to light and temperature. J Plankton Res 24:1173-1183. https://doi. org/10.1093/plankt/24.11.1173

17. Ungerer J, Lin P-C, Chen H-Y, Pakrasi HB (2018) Adjustments to Photosystem Stoichiometry and Electron Transfer Proteins Are Key to the Remarkably Fast Growth of the Cyanobacterium Synechococcus elongatus UTEX 2973. mBio 9. https://doi.org/ 10.1128/mBio.02327-17

18. Cheung MY, Liang S, Lee J (2013) Toxin-producing cyanobacteria in freshwater: A review of the problems, impact on drinking water safety, and efforts for protecting public health. J Microbiol 51:1-10. https://doi.org/10.1007/s12275-013-2549-3

19. Engene N, Rottacker EC, Kastovsky J, Byrum T, Choi H, Ellisman MH, Komarek J, Gerwick WH (2012) Moorea 
producens gen. nov., sp. nov. and Moorea bouillonii comb. nov., tropical marine cyanobacteria rich in bioactive secondary metabolites. Int J Syst Evol Microbiol 62:1171-1178. https://doi.org/10. 1099/ijs.0.033761-0

20. Leao T, Castelão G, Korobeynikov A, Monroe EA, Podell S, Glukhov E, Allen EE, Gerwick WH, Gerwick L (2017) Comparative genomics uncovers the prolific and distinctive metabolic potential of the cyanobacterial genus Moorea. Proc Natl Acad Sci U S A 114:3198-3203. https://doi.org/10.1073/pnas. 1618556114

21. Nunnery JK, Mevers E, Gerwick WH (2010) Biologically active secondary metabolites from marine cyanobacteria. Curr Opin Biotechnol 21:787-793. https://doi.org/10.1016/j.copbio.2010. 09.019

22. Afonso TB, Costa MS, Rezende de Castro R, Freitas S, Silva A, Schneider MPC, Martins R, Leão PN (2016) Bartolosides E-K from a Marine Coccoid Cyanobacterium. J Nat Prod 79:2504 2513. https://doi.org/10.1021/acs.jnatprod.6b00351

23. Burja A, Banaigs B, Abou-Mansour E, Burgess J, Wright P (2001) 832 Marine cyanobacteria - a prolific source of natural products. Tetrahedron 57:9347-9377. https://doi.org/10.1016/S00404020(01)00931-0

24. Chang Z, Sitachitta N, Rossi JV, Roberts MA, Flatt PM, Jia J, Sherman DH, Gerwick WH (2004) Biosynthetic pathway and gene cluster analysis of curacin A, an antitubulin natural product from the tropical marine cyanobacterium Lyngbya majuscula. J Nat Prod 67:1356-1367. https://doi.org/10.1021/np0499261

25. Edwards DJ, Marquez BL, Nogle LM, McPhail K, Goeger DE, Roberts MA, Gerwick WH (2004) Structure and biosynthesis of the jamaicamides, new mixed polyketide-peptide neurotoxins from the marine cyanobacterium Lyngbya majuscula. Chem Biol 11:817-833. https://doi.org/10.1016/j.chembiol.2004.03.030

26. Gu L, Wang B, Kulkarni A, Geders TW, Grindberg RV, Gerwick L, Håkansson K, Wipf P, Smith JL, Gerwick WH, Sherman DH (2009) Metamorphic enzyme assembly in polyketide diversification. Nature 459:731-735. https://doi.org/10.1038/nature07870

27. Gunasekera SP, Imperial L, Garst C, Ratnayake R, Dang LH, Paul VJ, Luesch H (2016) Caldoramide, a modified pentapeptide from the marine cyanobacterium Caldora penicillata. J Nat Prod 79: 1867-1871. https://doi.org/10.1021/acs.jnatprod.6b00203

28. Jones AC, Monroe EA, Podell S, Hess WR, Klages S, Esquenazi E, Niessen S, Hoover H, Rothmann M, Lasken RS, Yates JR, Reinhardt R, Kube M, Burkart MD, Allen EE, Dorrestein PC, Gerwick WH, Gerwick L (2011) Genomic insights into the physiology and ecology of the marine filamentous cyanobacterium Lyngbya majuscula. Proc Natl Acad Sci U S A 108:8815-8820. https://doi.org/10.1073/pnas.1101137108

29. Kleigrewe K, Gerwick L, Sherman DH, Gerwick WH (2016) Unique marine derived cyanobacterial biosynthetic genes for chemical diversity. Nat Prod Rep 33:348-364. https://doi.org/10. 1039/C5NP00097A

30. Mevers E, Byrum T, Gerwick WH (2013) Parguerene and precarriebowmide, two classes of lipopeptides from the marine cyanobacterium Moorea producens. J Nat Prod 76:1810-1814. https://doi.org/10.1021/np400347f

31. Al-Awadhi FH, Law BK, Paul VJ, Luesch H (2017) Grassystatins D-F, potent aspartic protease inhibitors from marine cyanobacteria as potential antimetastatic agents targeting invasive breast cancer. J Nat Prod 80:2969-2986. https://doi.org/10.1021/acs.jnatprod. $7 \mathrm{~b} 00551$

32. Al-Awadhi FH, Salvador LA, Law BK, Paul VJ, Luesch H (2017) Kempopeptin C, a novel marine-derived serine protease inhibitor targeting invasive breast cancer. Mar Drugs 15:290. https://doi. org/10.3390/md15090290
33. Wang M, Zhang J, He S, Yan X (2017) A Review Study on Macrolides Isolated from Cyanobacteria. Mar Drugs 15. https:// doi.org/10.3390/md15050126

34. Dittmann E, Fewer DP, Neilan BA (2013) Cyanobacterial toxins: biosynthetic routes and evolutionary roots. FEMS Microbiol Rev 37:23-43. https://doi.org/10.1111/j.1574-6976.2012.12000.x

35. Welker M, von Döhren H (2006) Cyanobacterial peptides - nature's own combinatorial biosynthesis. FEMS Microbiol Rev 30: 530-563. https://doi.org/10.1111/j.1574-6976.2006.00022.x

36. Sweet MJ, Bythell JC, Nugues MM (2013) Algae as Reservoirs for Coral Pathogens. PLoS One 8. https://doi.org/10.1371/journal. pone.0069717

37. Walter JM, Tschoeke DA, Meirelles PM, de Oliveira L, Leomil L, Tenório M, Valle R, Salomon PS, Thompson CC, Thompson FL (2016) Taxonomic and Functional Metagenomic Signature of Turfs in the Abrolhos Reef System (Brazil). PLoS One 11: e0161168. https://doi.org/10.1371/journal.pone.0161168

38. Wild C, Jantzen C, Kremb SG (2014) Turf algae-mediated coral damage in coastal reefs of Belize, Central America. Peer J 2:e571. https://doi.org/10.7717/peerj.571

39. Knowlton N, Jackson JBC (2008) Shifting baselines, local impacts, and global change on coral reefs. PLoS Biol 6:e54. https:/ doi.org/10.1371/journal.pbio.0060054

40. Barott KL, Rohwer FL (2012) Unseen players shape benthic competition on coral reefs. Trends Microbiol 20:621-628. https://doi. org/10.1016/j.tim.2012.08.004

41. De'ath G, Lough JM, Fabricius KE (2009) Declining coral calcification on the Great Barrier Reef. Science 323:116-119. https:// doi.org/10.1126/science. 1165283

42. Dinsdale EA, Pantos O, Smriga S, Edwards RA, Angly F, Wegley L, Hatay M, Hall D, Brown E, Haynes M, Krause L, Sala E, Sandin SA, Thurber RV, Willis BL, Azam F, Knowlton N, Rohwer F (2008) Microbial ecology of four coral atolls in the Northern Line Islands. PLoS One 3. https://doi.org/10.1371/ journal.pone. 0001584

43. Dinsdale EA, Rohwer F (2011) Fish or Germs? Microbial Dynamics Associated with Changing Trophic Structures on Coral Reefs. In: Dubinsky Z, Stambler N (eds) Coral Reefs: An Ecosystem in Transition. Springer Netherlands, Dordrecht, pp 231-240

44. Jackson JB, Kirby MX, Berger WH, Bjorndal KA, Botsford LW, Bourque BJ, Bradbury RH, Cooke R, Erlandson J, Estes JA, Hughes TP, Kidwell S, Lange CB, Lenihan HS, Pandolfi JM, Peterson CH, Steneck RS, Tegner MJ, Warner RR (2001) Historical overfishing and the recent collapse of coastal ecosystems. Science 293:629-637. https://doi.org/10.1126/science. 1059199

45. Silveira CB, Cavalcanti GS, Walter JM, Silva-Lima AW, Dinsdale EA, Bourne DG, Thompson CC, Thompson FL (2017) Microbial processes driving coral reef organic carbon flow. FEMS Microbiol Rev 41:575-595. https://doi.org/10.1093/femsre/fux018

46. Guillard RRL, Ryther JH (1962) Studies of marine planktonic diatoms: I. Cyclotella nana Hustedt, and Detonula confervacea (Cleve) Gran. Can J Microbiol 8:229-239. https://doi.org/10. 1139/m62-029

47. Guillard RRL (1975) Culture of phytoplankton for feeding marine inverterbrates. In: Smith WL, Chanley MH (eds) Culture of Marine Invertebrate Animals. Plenum Press, New York, NY, pp 26-60

48. Ferris MJ, Hirsch CF (1991) Method for isolation and purification of cyanobacteria. Appl Environ Microbiol 57(5):1448-1452.7

49. Paul R, Jinkerson RE, Buss K, Steel J, Mohr R, Hess WR, Chen M, Fromme P (2014) Draft genome sequence of the filamentous cyanobacterium Leptolyngbya sp. strain Heron Island J, exhibiting chromatic acclimation. Genome Announc 2(1): e01166-e01113. https://doi.org/10.1128/genomeA.01166-13 
50. Tenório MMB, Le Borgne R, Rodier M, Neveux J (2005) The impact of terrigeneous inputs on the Bay of Ouinné (New Caledonia) phytoplankton communities: A spectrofluorometric and microscopic approach. Estuar Coast Shelf Sci 64:531-545. https://doi.org/10.1016/j.ecss.2005.02.030

51. Bennett A, Bogorad L (1973) Complementary chromatic adaption in a filamentous blue-green alga. J Cell Biol 58:419-435

52. Bryant DA, Guglielmi G, de Marsac NT, Castets AM, CohenBazire G (1979) The structure of cyanobacterial phycobilisomes: a model. Arch Microbiol 123:113-127. https://doi.org/10.1007/ BF00446810

53. Wilson ST, Böttjer D, Church MJ, Karl DM (2012) Comparative assessment of nitrogen fixation methodologies, conducted in the oligotrophic North Pacific Ocean. Appl Environ Microbiol 78: 6516-6523. https://doi.org/10.1128/AEM.01146-12

54. Andrews S (2010) FastQC: a quality control tool for high throughput sequence data. Available: http://www.bioinformatics. babraham.ac.uk/projects/fastqc

55. Gordon, A, Hannon, GJ (2010) FASTX-Toolkit. Available: http:// hannonlab.cshl.edu/fastx toolkit/index.html

56. Schmieder R, Edwards R (2011) Quality control and preprocessing of metagenomic datasets. Bioinformatics (Oxford, England) 27:863-864. https://doi.org/10.1093/bioinformatics/btr026

57. Zerbino DR, Birney E (2008) Velvet: Algorithms for de novo short read assembly using de Bruijn graphs. Genome Res 18: 821-829. https://doi.org/10.1101/gr.074492.107

58. Dick GJ, Andersson AF, Baker BJ, Simmons SL, Thomas BC, Yelton AP, Banfield JF (2009) Community-wide analysis of microbial genome sequence signatures. Genome Biol 10:R85. https://doi.org/10.1186/gb-2009-10-8-r85

59. Cornet L, Meunier L, Vlierberghe MV, Léonard RR, Durieu B, Lara Y, Misztak A, Sirjacobs D, Javaux EJ, Philippe H, Wilmotte A, Baurain D (2018) Consensus assessment of the contamination level of publicly available cyanobacterial genomes. PLoS One 13: e0200323. https://doi.org/10.1371/journal.pone.0200323

60. Bonfield JK, Whitwham A (2010) Gap5 - editing the billion fragment sequence assembly. Bioinformatics 26:1699-1703. https:// doi.org/10.1093/bioinformatics/btq268

61. Bankevich A, Nurk S, Antipov D, Gurevich AA, Dvorkin M, Kulikov AS, Lesin VM, Nikolenko SI, Pham S, Prjibelski AD, Pyshkin AV, Sirotkin AV, Vyahhi N, Tesler G, Alekseyev MA, Pevzner PA (2012) SPAdes: A New Genome Assembly Algorithm and Its Applications to Single-Cell Sequencing. J Comput Biol 19:455-477. https://doi.org/10.1089/cmb.2012. 0021

62. Gurevich A, Saveliev V, Vyahhi N, Tesler G (2013) QUAST: Quality assessment tool for genome assemblies. Bioinformatics 29:1072-1075. https://doi.org/10.1093/bioinformatics/btt086

63. Parks DH, Imelfort M, Skennerton CT, Hugenholtz P, Tyson GW (2015) CheckM: assessing the quality of microbial genomes recovered from isolates, single cells, and metagenomes. Genome Res 25:1043-1055. https://doi.org/10.1101/gr.186072.114

64. Seemann T (2014) Prokka: Rapid prokaryotic genome annotation. Bioinformatics 30:2068-2069. https://doi.org/10.1093/ bioinformatics/btu153

65. Hyatt D, Chen G-L, Locascio PF, Land ML, Larimer FW, Hauser LJ (2010) Prodigal: prokaryotic gene recognition and translation initiation site identification. BMC Bioinformatics 11:119. https:// doi.org/10.1186/1471-2105-11-119

66. Lagesen K, Hallin P, Rødland EA, Staerfeldt H-H, Rognes T, Ussery DW (2007) RNAmmer: consistent and rapid annotation of ribosomal RNA genes. Nucleic Acids Res 35:3100-3108. https://doi.org/10.1093/nar/gkm160

67. Lowe TM, Chan PP (2016) tRNAscan-SE On-line: integrating search and context for analysis of transfer RNA genes. Nucleic Acids Res 44:W54-W57. https://doi.org/10.1093/nar/gkw413
68. Edelstein M, Gehrke F, Hopf S, Jehl M, Oswald A, Rattei T (2003) Genome skew, version 1.0. Technische Universitaet Muenchen, Genome Oriented Bioinformatics. Available at: http://genskew. csb.univie.ac.at/

69. Grant JJR, Arantes AS, Stothard P, Carver T, Rutherford K, Berriman M, Rajandream M-A, Barrell B, Parkhill J, Elnitski L, Burhans R, Riemer C, Hardison R, Miller W, Hallin P, Binnewies T, Ussery D, Tatusov R, Fedorova N, Jackson J, Jacobs A, Kiryutin B, Koonin E, Krylov D, Mazumder R, Mekhedov S, Nikolskaya A, Rao B, Smirnov S, Sverdlov A, Vasudevan S, Wolf Y, Yin J, Natale D, Benson D, Karsch-Mizrachi I, Lipman D, Ostell J, Sayers E, Altschul S, Madden T, Schäffer A, Zhang J, Zhang Z, Miller W, Lipman D, Stothard P, Wishart D, Grant JJR, Stothard P, Krzywinski M, Schein J, Birol I, Connors J, Gascoyne R, Horsman D, Jones S, Marra M, Alikhan N-F, Petty N, Zakour N B, Beatson S (2012) Comparing thousands of circular genomes using the CGView Comparison Tool. BMC Genomics 13:202. https://doi.org/10.1186/1471-2164-13-202

70. Pruesse E, Peplies J, Glöckner FO (2012) SINA: accurate highthroughput multiple sequence alignment of ribosomal RNA genes. Bioinformatics 28:1823-1829. https://doi.org/10.1093/ bioinformatics/bts 252

71. Pruesse E, Quast C, Knittel K, Fuchs BM, Ludwig W, Peplies J, Glöckner FO (2007) SILVA: a comprehensive online resource for quality checked and aligned ribosomal RNA sequence data compatible with ARB. Nucleic Acids Res 35:7188-7196. https://doi. org/10.1093/nar/gkm864

72. Quast C, Pruesse E, Yilmaz P, Gerken J, Schweer T, Yarza P, Peplies J, Glöckner FO (2013) The SILVA ribosomal RNA gene database project: improved data processing and web-based tools. Nucleic Acids Res 41:D590-D596. https://doi.org/10.1093/nar/ gks1219

73. Katoh K, Standley DM (2013) MAFFT multiple sequence alignment software version 7: improvements in performance and usability. Mol Biol Evol 30:772-780. https://doi.org/10.1093/ molbev/mst010

74. Castresana J (2000) Selection of conserved blocks from multiple alignments for their use in phylogenetic analysis. Mol Biol Evol 17:540-552. https://doi.org/10.1093/oxfordjournals.molbev. a026334

75. Talavera G, Castresana J (2007) Improvement of phylogenies after removing divergent and ambiguously aligned blocks from protein sequence alignments. Syst Biol 56:564-577. https://doi.org/10. 1080/10635150701472164

76. Tamura K, Stecher G, Peterson D, Filipski A, Kumar S (2013) MEGA6: Molecular Evolutionary Genetics Analysis version 6.0. Mol Biol Evol 30:2725-2729. https://oi.org/10.1093/molbev/ mst197

77. Tajima F, Nei M (1984) Estimation of evolutionary distance between nucleotide sequences. Mol Biol Evol 1:269-285. https:// doi.org/10.1093/oxfordjournals.molbev.a040317

78. Shih PM, Wu D, Latifi A, Axen SD, Fewer DP, Talla E, Calteau A, Cai F, Tandeau de Marsac N, Rippka R, Herdman M, Sivonen K, Coursin T, Laurent T, Goodwin L, Nolan M, Davenport KW, Han CS, Rubin EM, Eisen JA, Woyke T, Gugger M, Kerfeld CA (2013) Improving the coverage of the cyanobacterial phylum using diversity-driven genome sequencing. Proc Natl Acad Sci U S A 110:1053-1058. https://doi.org/10.1073/pnas.1217107110

79. Wu M, Eisen JA (2008) A simple, fast, and accurate method of phylogenomic inference. Genome Biol 9:R151. https://doi.org/10. 1186/gb-2008-9-10-r151

80. Komárek J, Kaštovský J, Mareš J, Johansen J (2014) Taxonomic classification of cyanoprokaryotes (cyanobacterial genera), using a polyphasic approach. Preslia 295-335 
81. Wu M, Scott AJ (2012) Phylogenomic analysis of bacterial and archaeal sequences with AMPHORA2. Bioinformatics 28:10331034. https://doi.org/10.1093/bioinformatics/bts079

82. Edgar RC (2004) MUSCLE: multiple sequence alignment with high accuracy and high throughput. Nucleic Acids Res 32:17921797. https://doi.org/10.1093/nar/gkh340

83. Stamatakis A (2006) RAxML-VI-HPC: maximum likelihoodbased phylogenetic analyses with thousands of taxa and mixed models. Bioinformatics 22:2688-2690. https://doi.org/10.1093/ bioinformatics/btl446

84. Rambaut A (2012) FigTree v.1.4.2: tree figure drawing tool

85. Konstantinidis KT, Tiedje JM (2005) Genomic insights that advance the species definition for prokaryotes. Proc Natl Acad Sci U S A 102:2567-2572. https://doi.org/10.1073/pnas.0409727102

86. Karlin S, Mrázek J, Campbell AM (1997) Compositional biases of bacterial genomes and evolutionary implications. J Bacteriol 179: 3899-3913. https://doi.org/10.1128/jb.179.12.3899-3913.1997

87. Auch AF, von Jan M, Klenk H-P, Göker M (2010) Digital DNADNA hybridization for microbial species delineation by means of genome-to-genome sequence comparison. Stand Genomic Sci 2: 117-134. https://doi.org/10.4056/sigs.531120

88. Auch AF, Klenk H-P, Göker M (2010) Standard operating procedure for calculating genome-to-genome distances based on highscoring segment pairs. Stand Genomic Sci 2:142-148. https://doi. org/10.4056/sigs. 541628

89. Meier-Kolthoff JP, Auch AF, Klenk H-P, Göker M (2013) Genome sequence-based species delimitation with confidence intervals and improved distance functions. BMC bioinformatics 14: 60. https://doi.org/10.1186/1471-2105-14-60

90. R Core Team (2013) R: a language and environment for statistical computing. R Foundation for Statistical Computing, Vienna, Austria

91. Aziz RK, Bartels D, Best AA, DeJongh M, Disz T, Edwards RA, Formsma K, Gerdes S, Glass EM, Kubal M, Meyer F, Olsen GJ, Olson R, Osterman AL, Overbeek RA, McNeil LK, Paarmann D, Paczian T, Parrello B, Pusch GD, Reich C, Stevens R, Vassieva O, Vonstein V, Wilke A, Zagnitko O (2008) The RAST Server: rapid annotations using subsystems technology. BMC Genomics 9:75. https://doi.org/10.1186/1471-2164-9-75

92. Overbeek R, Olson R, Pusch GD, Olsen GJ, Davis JJ, Disz T, Edwards RA, Gerdes S, Parrello B, Shukla M, Vonstein V, Wattam AR, Xia F, Stevens R (2014) The SEED and the Rapid Annotation of microbial genomes using Subsystems Technology (RAST). Nucleic Acids Res 42:D206-D214. https://doi.org/10. 1093/nar/gkt1226

93. Buchfink B, Xie C, Huson DH (2014) Fast and sensitive protein alignment using DIAMOND. Nat Methods 12:59-60. https://doi. org/10.1038/nmeth.3176

94. Weber T, Blin K, Duddela S, Krug D, Kim HU, Bruccoleri R, Lee SY, Fischbach MA, Muller R, Wohlleben W, Breitling R, Takano E, Medema MH (2015) antiSMASH 3.0-a comprehensive resource for the genome mining of biosynthetic gene clusters. Nucleic Acids Res 43:237-243. https://doi.org/10.1093/nar/ gkv437

95. Langmead B, Salzberg SL (2012) Fast gapped-read alignment with Bowtie 2. Nat Methods 9:357-359. https://doi.org/10.1038/ nmeth.1923.Fast

96. Iverson V, Morris RM, Frazar CD, Berthiaume CT, Morales RL, Armbrust EV (2012) Untangling genomes from metagenomes: revealing an uncultured class of marine Euryarchaeota. Science 335:587-590. https://doi.org/10.1126/science.1212665

97. dos Reis VM, Karez CS, Mariath R, de Moraes FC, de Carvalho RT, Brasileiro PS, da Bahia RG, da Lotufo TMC, Ramalho LV, de Moura RL, Francini-Filho RB, Pereira-Filho GH, Thompson FL, Bastos AC, Salgado LT, Amado-Filho GM (2016) Carbonate Production by Benthic Communities on Shallow Coralgal Reefs of Abrolhos Bank, Brazil. PLoS One 11:e0154417. https://doi.org/ 10.1371/journal.pone.0154417

98. Gutu A, Kehoe DM (2012) Emerging perspectives on the mechanisms, regulation, and distribution of light color acclimation in cyanobacteria. Mol Plant 5:1-13. https://doi.org/10.1093/mp/ ssr054

99. Tandeau de Marsac N (1977) Occurrence and nature of chromatic adaptation in cyanobacteria. J Bacteriol 130:82-91

100. Walter JM, Coutinho FH, Dutilh BE, Swings J, Thompson FL, Thompson CC (2017) Ecogenomics and Taxonomy of Cyanobacteria Phylum. Front Microbiol 8:2132. https://doi.org/ 10.3389/fmicb.2017.02132

101. Francini-Filho RB, Coni EOC, Meirelles PM, Amado-Filho GM, Thompson FL, Pereira-Filho GH, Bastos AC, Abrantes DP, Ferreira CM, Gibran FZ, Güth AZ, Sumida PYG, Oliveira NL, Kaufman L,Minte-Vera CV, Moura RL (2013) Dynamics of coral reef benthic assemblages of the Abrolhos Bank, Eastern Brazil: inferences on natural and anthropogenic drivers. PLoS One 8: e54260. https://doi.org/10.1371/journal.pone.0054260

102. Dufresne A, Ostrowski M, Scanlan DJ, Garczarek L, Mazard S, Palenik B, Paulsen IT, de Marsac NT, Wincker P, Dossat C, Ferriera S, Johnson J, Post AF, Hess WR, Partensky F (2008) Unraveling the genomic mosaic of a ubiquitous genus of marine cyanobacteria. Genome Biol 9:R90. https://doi.org/10.1186/gb2008-9-5-r90

103. Dagan T, Roettger M, Stucken K, Landan G, Koch R, Major P, Gould SB, Goremykin VV, Rippka R, De Marsac NT, Gugger M, Lockhart PJ, Allen JF, Brune I, Maus I, Pühler A, Martin WF (2013) Genomes of stigonematalean cyanobacteria (subsection $\mathrm{V}$ ) and the evolution of oxygenic photosynthesis from prokaryotes to plastids. Genome Biology and Evolution 5:31-44. https://doi. org/10.1093/gbe/evs117

104. Gevers D, Cohan FM, Lawrence JG, Spratt BG, Coenye T, Feil EJ, Stackebrandt E, Van de Peer Y, Vandamme P, Thompson FL, Swings J (2005) Re-evaluating prokaryotic species. Nat Rev Microbiol 3:733-739. https://doi.org/10.1038/nrmicro1236

105. Han K, Li Z, Peng R, Zhu L, Zhou T, Wang L, Li S, Zhang X, Hu W, Wu Z, Qin N, Li Y (2013) Extraordinary expansion of a Sorangium cellulosum genome from an alkaline milieu. Sci Rep 3:1-7. https://doi.org/10.1038/srep02101

106. Huntley S, Zhang Y, Treuner-Lange A, Kneip S, Sensen CW, Søgaard-Andersen L (2012) Complete genome sequence of the fruiting myxobacterium Corallococcus coralloides DSM 2259. J Bacteriol 194:3012-3013. https://doi.org/10.1128/JB.00397-12

107. Schneiker S, Perlova O, Kaiser O, Gerth K, Alici A, Altmeyer MO, Bartels D, Bekel T, Beyer S, Bode E, Bode HB, Bolten CJ, Choudhuri JV, Doss S, Elnakady YA, Frank B, Gaigalat L, Goesmann A, Groeger C, Gross F, Jelsbak L, Jelsbak L, Kalinowski J, Kegler C, Knauber T, Konietzny S, Kopp M, Krause L, Krug D, Linke B, Mahmud T, Martinez-Arias R, McHardy AC, Merai M, Meyer F, Mormann S, Muñoz-Dorado J, Perez J, Pradella S, Rachid S, Raddatz G, Rosenau F, Rückert C, Sasse F, Scharfe M, Schuster SC, Suen G, Treuner-Lange A, Velicer GJ, Vorhölter F-J, Weissman KJ, Welch RD, Wenzel SC, Whitworth DE, Wilhelm S, Wittmann C, Blöcker H, Pühler A, Müller R (2007) Complete genome sequence of the myxobacterium Sorangium cellulosum. Nat Biotechnol 25: 1281-1289. https://doi.org/10.1038/nbt1354

108. Thompson CC, Silva GGZ, Vieira NM, Edwards R, Vicente ACP, Thompson FL (2013) Genomic taxonomy of the genus Prochlorococcus. Microb Ecol 66:752-762. https://doi.org/10. 1007/s00248-013-0270-8

109. Thompson CC, Chimetto L, Edwards RA, Swings J, Stackebrandt E, Thompson FL (2013) Microbial genomic taxonomy. BMC Genomics 14:913. https://doi.org/10.1186/1471-2164-14-913 
110. Hirose Y, Shimada T, Narikawa R, Katayama M, Ikeuchi M (2008) Cyanobacteriochrome CcaS is the green light receptor that induces the expression of phycobilisome linker protein. Proc Natl Acad Sci U S A 105:9528-9533. https://doi.org/10.1073/pnas. 0801826105

111. Hirose Y, Narikawa R, Katayama M, Ikeuchi M (2010) Cyanobacteriochrome CcaS regulates phycoerythrin accumulation in Nostoc punctiforme, a group II chromatic adapter. Proc Natl Acad Sci U S A 107:8854-8859. https://doi.org/10.1073/ pnas. 1000177107

112. Bryant DA (1981) The photoregulated expression ofmultiple phycocyanin species: a general mechanism for the control of phycocyanin synthesis is chromatically adapting cyanobacteria. Eur J Biochem 119(2):425-429. https://doi.org/10.1111/j.1432-1033. 1981.tb05625.x

113. Mazel D, Houmard J, deMarsac NT (1988) A multigene family in Calothrix sp. PCC 7601 encodes phycocyanin, the major component of the cyanobacterial light-harvesting antenna. Mol Gen Genet MGG 211(2):296-304. https://doi.org/10.1007/ BF00330607

114. Bussell AN, Kehoe DM (2013) Control of a four-color sensing photoreceptor by a two-color sensing photoreceptor reveals complex light regulation in cyanobacteria. PNAS 110:12834-12839. https://doi.org/10.1073/pnas.1303371110

115. Gan F, Zhang S, Rockwell NC, Martin SS, Lagarias JC, Bryant DA (2014) Extensive remodeling of a cyanobacterial photosynthetic apparatus in far-red light. Science 345:1312-1317. https:// doi.org/10.1126/science. 1256963

116. Gan F, Shen G, Bryant D (2014) Occurrence of Far-Red light photoacclimation (FaRLiP) in diverse Cyanobacteria. Life 5:424. https://doi.org/10.3390/life5010004

117. Silva-Lima AW, Walter JM, Garcia GD, Ramires N, Ank G, Meirelles PM, Nobrega AF, Siva-Neto ID, Moura RL, Salomon PS, Thompson CC, Thompson FL (2015) Multiple Symbiodinium strains are hosted by the Brazilian endemic corals Mussismilia spp. Microb Ecol 70:301-310. https://doi.org/10.1007/s00248015-0573-z
118. Richardson LL, Miller AW, Broderick E, Kaczmarsky L, Gantar M, Stanić D, Sekar R (2009) Sulfide, microcystin, and the etiology of black band disease. Dis Aquat Org 87:79-90. https://doi.org/10. 3354/dao02083

119. Leão PN, Engene N, Antunes A, Gerwick WH, Vasconcelos V (2012) The chemical ecology of cyanobacteria. Nat Prod Rep 29: 372-391. https://doi.org/10.1039/c2np00075j

120. Cruz-Rivera E, Paul VJ (2007) Chemical deterrence of a cyanobacterial metabolite against generalized and specialized grazers. J Chem Ecol 33:213-217. https://doi.org/10.1007/ s10886-006-9212-y

121. Paz-Yepes J, Brahamsha B, Palenik B (2013) Role of a microcinC-like biosynthetic gene cluster in allelopathic interactions in marine Synechococcus. Proc Natl Acad Sci U S A 110:12030-12035. https://doi.org/10.1073/pnas.1306260110

122. Barott KL, Rodriguez-Mueller B, Youle M, Marhaver KL, Vermeij MJA, Smith JE, Rohwer FL (2012) Microbial to reef scale interactions between the reef-building coral Montastraea annularis and benthic algae. Proc Biol Sci 279:1655-1664. https://doi.org/10.1098/rspb.2011.2155

123. Charpy L, Casareto BE, Langlade MJ, Suzuki Y (2012) Cyanobacteria in coral reef ecosystems: a review. J Mar Biotechnol 2012:1-9. https://www.hindawi.com/journals/jmb/ 2012/259571/

124. Gregg A, Hatay M, Haas A, Robinett N, Barott K, Vermeij M, Marhaver K, Meirelles P, Thompson F, Rohwer F (2013) Biological oxygen demand optode analysis of coral reef-associated microbial communities exposed to algal exudates. Peer $\mathrm{J} 1$ : e107. https://doi.org/10.7717/peerj.107

125. Ribeiro FV, Sá JA, Fistarol GO, Salomon PS, Pereira RC, Souza MLAM, Neves LM, Amado-Filho GM, Francini-Filho RB, Salgado LT, Bastos AC, Pereira-Filho GH, Moraes FC, Moura RL (2018) Long-term effects of competition and environmental drivers on the growth of the endangered coral Mussismilia braziliensis (Verril, 1867). Peer J 6:e5419. https://doi.org/10. 7717/peerj.5419 